\title{
Bulanık ve Gri COPRAS Yöntemleri Kullanılarak Tedarikçi Seçim Modeli Geliştirilmesi*
}

\author{
Bahadır Fatih YILDIRIM**, Mehpare TIMOR***
}

ÖZ

Günümüzde artan rekabet koşulları işletmelerin tedarik zinciri üzerinde yer alan tedarikçi işletme ve müşterileri ile olan ilişkilerini yeniden yapılandırmayı zorunlu hale getirmiştir. İşletmelerin tedarikçileri doğru bir şekilde belirlemeleri rekabet için hayati önem arz etmektedir. Bu çalışmada otomotiv sektöründe faaliyet gösteren bir işletmenin tedarikçi seçim süreci çok kriterli karar verme problemi olarak ele alınmış ve incelenmiştir. Çalışmada öncelikli olarak tedarikçi seçimi karar sürecinde etkili olan kriterler belirlenmiş ve Bulanık Analitik Hiyerarşi Prosesi kullanılarak önem dereceleri tespit edilmiştir. Analiz sonucunda işletmenin tedarikçi seçim sürecinde en önemli kriter, tedarikçi firmanın sahip olduğu üretim yetenekleri kriteri, en az öneme sahip kriter ise dağıtım kriteri olmuştur. Tedarikçi alternatiflerin değerlendirilmesinde Bulanık ve Gri COPRAS yöntemleri iki ayrı model olarak kullanılmıştır. Analiz sonuçlarına göre her iki yöntem ile elde edilen bulguların tutarlı olduğu saptanmıştır. Sonuç olarak tedarikçi seçimi karar probleminde Bulanık AHP + COPRAS-F ve Bulanık AHP + COPRAS-G yöntemlerinin kolay ve hızlı sonuç ürettiği ve başarılı ile uygulanabileceği görülmüştür.

Anahtar Kelimeler: Bulanık AHP, Bulanık COPRAS, Gri COPRAS, Tedarikçi Seçimi, Otomotiv Sektörü.

JEL Sinıflandırması: C44, D81, D89

\section{Development of a Supplier Selection Model Using Fuzzy and Grey COPRAS Methods}

\begin{abstract}
Nowadays, increasing competition conditions necessitate the restructuring of the relations of the enterprises with the supplier enterprise and customers on the supply chain. It is vital for businesses to determine the suppliers correctly. In this study, the criteria which are effective in the decision of supplier selection were determined and the importance levels were determined by using Fuzzy Analytic Hierarchy Process. As a result of the analysis, the most important criterion in the supplier selection process of the enterprise is the criterion of production capabilities of the supplier and the criteria with the least importance is the distribution criterion. Fuzzy and Grey COPRAS methods were used as two separate models in the evaluation of supplier alternatives. According to the results of the analysis, the findings obtained by both methods were found to be consistent. As a result, it has been seen that the Fuzzy AHP + COPRAS-F and Fuzzy AHP + COPRAS-G methods in supplier selection decision problem produce easy and fast results and can be applied successfully.
\end{abstract}

Keywords: Fuzzy AHP, Fuzzy COPRAS, Grey COPRAS, Supplier Selection, Automotive Sector.

JEL Classification: C44, D81, D89

Geliş Tarihi / Received: 03.04.2019 Kabul Tarihi / Accepted: 07.05.2019

\footnotetext{
* Bu çalışma Prof. Dr. Mehpare TİMOR danışmanlığında İstanbul Üniversitesi Sosyal Bilimler Enstitüsü İşletme Anabilim Dalı, Sayısal Yöntemler Bilim Dalında hazırlanan "Fuzzy ve Grey COPRAS Yöntemleri İle Çok Kriterli Karar Verme Uygulaması" başlıklı doktora tezinden üretilmiş ve İstanbul Üniversitesi Bilimsel Araştırma Projeleri Birimi tarafindan 54740 no'lu proje ile desteklenmiştir.

** Arş. Gör. Dr., İstanbul Üniversitesi, Ulaştırma ve Lojistik Fakültesi, bahadirf.yildirim@istanbul.edu.tr, ORCID: 0000-0002-0475-741X

**** Prof. Dr., İstanbul Üniversitesi, İșletme Fakültesi, timorm@ istanbul.edu.tr, ORCID: 0000-0002-9782-545X
} 


\section{GİRIŞ}

İşletmeler için sıkı rekabet ortamından hiper rekabet ortamına geçişin tartışıldığ 1 günümüzde işletmeler arası rekabetin değil, işletmelerin oluşturduğu tedarik zincirlerinin arasındaki rekabetin başarıda daha fazla katkısı olduğu kabul edilmektedir. Yaşanan teknolojik gelişmeler, küreselleşme, inovasyon gibi olgular ile pazar taleplerinin daha dinamik hale gelmesi sonucunu doğurmuştur. Taleplerin eşanlı olarak karşılanması işletmelerin rekabet ortamında tutunabilmesi için önem arz etmektedir. Dinamik pazar taleplerine çabuk tepki verilebilmesi ancak tedarikçi, üretici, dağıtıcı, servis sağlayıcı ve müşterilerin tedarik zincirine entegre edilmesi ve zincir üzerindeki ürün, para ve bilgi akışının koordinasyonunun başarılı şekilde yönetilmesi ile sağlanabilmektedir.

Günümüzde işletmeler, rekabet üstünlüğü elde etmek için paydaşları ile ilişkilerinin önemini kavramış dolayısıyla tedarik zinciri üzerinde yer alan tedarikçi ve müşterileri ile olan ilişkilerini yeniden yapılandırmaya başlamışlardır.

Özellikle üretim işletmelerinde üretim yapabilme kabiliyeti tedarik zincirinin en zayıf üyesinin üretim kabiliyeti oranında olduğu düşünüldüğünde tedarikçilerle geliştirilecek işbirliklerinin kalitenin artırılması, maliyetin düşürülmesi, üretim ve dağıtım esnekliğinin artırılması dolayısıyla müşteri memnuniyetinin artırılması gibi birçok konuda iyileşmelere neden olacağı görülecektir.

Tekstil, otomotiv gibi üretim odaklı sektörlerde işletmelerin kendi içlerinde yaptıkları üretimin maliyeti ürünün toplam maliyetinin \%50'sini geçmemekte (Ekonomi Bakanlığı, 2015), işletmelerin y1llık giderleri içerisinde satın alma giderleri, toplam giderlerin \%50'si ile \%90'1 arasında bir orana sahip olmaktadır (De Boer vd., 2001). Güncel bir örnek olarak Porsche marka araçların maliyetinde işletmenin maliyetin \%20'sini oluşturacak oranda üretim faaliyeti gösterdiği bilinmektedir. Tüm bu sayılanlar bir bütün olarak düşünüldüğünde işletmeler için tedarik sürecinin yönetilmesinin hayati olduğu görülmektedir.

İşletmelerin tüm yönetsel süreçlerinde olduğu gibi tedarik zinciri yönetimi sürecinde de yöneticilerin bir takım karar verme problemleri ile karşılaşmaktadır. Tedarik zincirini oluştururken çalışılacak tedarikçiler, dağıtıcılar, servis sağlayıcılar, üreticiler ve hatta müşterilerin belirlenmesi, tedarikçilerden hangi ürünün tedarik edileceği, ne miktarda ve sıklıkta ürün tedarik edileceği gibi birçok karar problemi işletmeler tarafından incelenmektedir.

Tedarik zinciri oluşturulurken işletmelerin ihtiyaçlarına cevap verebilecek kabiliyette tedarikçileri belirleme süreci, birden çok nitel ve nicel kriterin karar sürecinde etkili olduğu bir karar problemi olarak işletmeler için önem arz etmektedir.

En genel ifade ile tedarikçi seçim problemi olarak adlandırılabilecek bu karar problemi, literatürde birçok araştırmacı tarafından incelenmiş, farklı yöntemler ile çözüm önerilerinde bulunulmuştur.

$\mathrm{Bu}$ çalışmada Tedarikçi Seçimi karar problemi bir Çok Kriterli Karar Verme Problemi (ÇKKV) olarak ele alınarak modellenmiştir. COPRAS yöntemine bulanık mantık ve gri sistem teorilerinin entegre edilerek kullanıldığı Bulanık COPRAS (COPRAS-F) ve Gri COPRAS (COPRAS-G) yöntemleri Bulanık AHP yöntemi ile birlikte kullanılarak iklimlendirme sektöründe faaliyet gösteren bir işletmenin tedarikçi seçim problemi modellenmiştir. COPRAS-F ve COPRAS-G yöntemleri alternatiflerin değerlendirilmesinde farklı iki model olarak kullanılarak karşılaştııılmıştır. 


\section{TEDARIKCÇI SEÇIMM PROBLEMI}

İşletmelerin varlıklarını sürdürebilmek için üretim yapmak, üretim yapmak için de ham madde, malzeme, parça gibi girdileri üretim süreçlerine dâhil etmek zorundadırlar.

İşletmelerin üretim süreçlerine dâhil etmek zorunda oldukları tüm girdileri kendilerinin üretmesi mümkün değildir. Artan ve değişen rekabet koşulları da işletmelerin üretim sürecinde gerçekleştirilen tüm faaliyetleri tek başına yerine getirmesini ve bu faaliyetlerin her birinde uzmanlaşmasını imkânsız hale getirmiştir (Timur, 2013). Bu durumda diş bir kaynaktan bu girdilerin sağlanması zorunluluğu ortaya çıkmaktadır. Otomobil üretimi yapan bir işletme düşünüldüğünde, bir otomobili oluşturan baz ham maddeden, en detaylı işleme tabi tutulmuş parçaya kadar genişletilebilecek tüm girdilerin üretici işletme tarafından imal edildiği varsayımı altında işletmenin gereksinim duyacağ teknoloji, iş gücü, finansman, tesis kapasitesi vb. sistem öğelerinin büyüklüğü ve beraberinde getireceği yönetsel problemler işletmenin etkinliğini olumsuz etkileyecektir.

Bir otomobil üreticisi işletmenin teknoloji geliştirmenin yanında otomobil üzerinde kullanılacak elektrik tesisatına ait kabloları ya da parçaların montajında kullanılacak vidaları da üretmesi işletme için rasyonel bir davranış olmayacaktır. Bu nedenle günümüzde işletmeler üretim derinliklerini azaltarak uzmanlık alanlarını tek bir odak noktasına indirgemeye çalışmaktadır (Kağnıcıŏglu, 2012).

İşletmelerin üretim süreçlerinde kullanacakları girdileri tedarikçilerden temin etmesi işletmeye rekabet avantajı sağlama, maliyetleri azaltma gibi birçok fayda sağlamakla birlikte bir takım yönetsel problemleri de beraberinde getirmektedir. İşletmenin üretiminin dişardan sürece dâhil olan başka birçok işletmeye bağlı olması, tedarik sonucu üretimini gerçekleştirdiği nihai ürünü son kullanıcıya/müşteriye işletme adına sunarak tedarik edilen üründen kaynaklı her sorunun sorumluluğunu üstlenmek gibi birçok husus işletmelerin üstesinden gelmesi gereken problemler olmaktadır. Bu problemlerin üstesinden gelmek üzere tedarik zinciri yönetimi kavramı geliştirilmiştir.

Tedarik zinciri yönetiminin başarılı olmasında zinciri oluşturan tarafların arasında iletişim, güven ve işbirliği önem arz etmektedir. Bu durum tedarikçi ile işletme arasındaki ilişki için de geçerli olduğundan işletmeler çalışacakları tedarikçilerini seçerken taraflar arası süreçlerin uyumlu olması gerekliliğini göz önünde bulundurmalıdırlar (Kağnıcıŏlu, 2012). İşletmenin süreçlerine uygun tedarikçi bulması oldukça zordur, işletmenin önem derecesini belirlediği kriterlere uygunluk bakımından tedarikçiler farklı kriterlerde birbirlerine üstünlük sağlayabilmektedir. Bu nedenle tedarikçi seçimi kompleks bir yapıya bürünmekte ve işletme tarafindan çözülmesi gereken bir karar problemine dönüşmektedir. Bu karar problemi en genel ifade ile tedarikçi seçim problemi olarak tanımlanabilir.

Tedarikçi seçimi, tedarik zinciri yönetimi içerisinde önemli bir süreç olmakla birlikte, kalite standartlarına uyum için de bir zorunluluk haline gelmiştir. Öyleki çoğu sektör için önemli bir katma değer kabul edilen TS EN ISO 9001 Kalite Yönetim Sisteminin tedarikçilerin anıldığı 7. 4. maddesinde,

"Kuruluş tedarikçilerini, kuruluş şartlarına uygun ürün sağlama yeteneği temelinde değerlendirmeli ve seçmelidir. Seçme, değerlendirme ve yeniden değerlendirme kriterleri oluşturulmalıdır."

ibaresine yer verilmiştir.

Tedarikçi seçim probleminde amaç, işletmenin gereksinim duyduğu ürünleri, uygun fiyattan, beklenen kalitede, istenen zamanda tedarik edebileceği tedarikçi ya da tedarikçileri belirlemektir (Özgörmüş vd., 2005). 
Tedarikçi seçim probleminde karar vericiler 3 tip karar karar problemi ile karşılaşmaktadır. Bu problemler, hangi ürün tedarik edileceği ve tedarik miktarı, hangi tedarikçiden ürünlerin tedarik edileceği ve hangi dönemlerde tedarik edileceğidir (Kağnıcıoğlu, 2012). Diğer bir ifadeyle tedarikçi seçim problemi, tedarik edilecek ürüne, tedarik kaynağı sayısına ve tedarikçi ile kurulacak işbirliği süresine göre farklı boyutlarda ele alınmaktadır.

Literatürde tedarikçi seçim problemlerinin çözümünde kullanılan yöntemleri ve kriterleri inceleyen ve farklı dönemleri farklı bakış açıları ile irdeleyen birçok literatür tarama çalışmaları mevcuttur. Bu çalışmaların ilklerinden olan ve en çok bilinen çalışma Weber vd. (1991) yapılan çalışmadır. Bu çalışmada tedarikçi seçiminde kullanılan kriterler ve yöntemler incelenmiştir. Dickson (1966) tarafından tedarikçi seçim kriterlerinin belirlenmesine yönelik olarak yapılmış çalışmayı temel alan bu makale de yazarlar toplamda 74 makaleyi inceleyerek tedarikçi seçiminde kullanılan kriterleri belirlemeye çalışmışlardır.

Weber vd. (1991) çalışmalarını izleyen dönemde Holt (1998), Degraeve vd. (2000)'in çalışmaları takip etmiş, sayılan bu çalışmaların devamı niteliğinde bir çalışmada De Boer vd. (2001) tedarikçi seçim sürecinde karar verme sürecini destekleyen yöntemleri inceledikleri bir çalışma yayımlamışlardır. Bu çalışmada kriterlerin belirlenmesi, belirlenen kriterlere göre tedarikçi alternatiflerinin ön değerlendirmeye tabi tutulması ve nihai kararın alınması süreçleri incelenmiş, kullanılan yöntemler sınıflanmıştır.

Bhutta ve Khurrum (2003) yılında yaptığı literatür taraması çalışmasında tedarikçi seçimi problemini tedarikçilerin seçimi ve tedarikçilerin değerlendirmesi başlıkları altında ele aldıktan sonra süreçte kullanılan yöntemleri, incelediği 68 hakemli dergiden 154 çalışmaya ait tanımsal istatistikler üzerinden değerlendirmiştir. Cheraghi vd. (2004), 1966-1990 ve 1990-2001 dönemlerini ayrı ayrı ele aldıkları çalışmalarında tedarikçi seçiminde kullanılan kriterleri inceleyerek süreçte en çok kullanılan kriterleri listelemeye çalışmışlardır.

Sönmez (2006), tedarikçi seçiminde kullanılan yöntemleri incelediği tez çalışmasında 1985-2005 yılları arasında yayımlanmış 147 hakemli makaleyi incelemiştir. Teze konu olan çalışmalar, kullanımını önerilen seçim kriterlerin vurgulandığı çalışmalar; karar verme sürecinde (seçim, değerleme, sıralama) kullanılacak yöntemlerin tanıtıldığı çalışmalar; alıcı-satıcı ilişkilerinin incelendiği çalışmalar; uluslararası tedarikçi seçimi uygulamalarının yapıldığı çalışmalar ve internet tabanlı pazarlarda tedarikçi seçiminin vurgulandığı çalışmalar olmak üzere 5 ana başlık altında incelenmiştir.

Aissaoui vd. (2007), çalışmalarında farklı bir bakış açısı ile tedarikçi seçiminde tedarik edilen ürünlerin niceliği üzerinden çalışmaları sınıflamışladır. Çalışma kapsamında tedarik edilen ürünün tek ya da birden fazla olması, tedarik döneminin tek ya da birden çok periyodda olması, tedarik sürecinde indirimin var olup olmamasını baz alarak çalışmaları konuları bakımından sınıflamışlardır.

Genovese vd. (2010) ise yeşil tedarikçi seçimi süreci üzerine hazırlanmış 15 çalışmayı inceledikleri yayınlarında yeşil tedarikçi seçiminde kullanılan çevresel kriterleri belirlemeye çalışmışlardır. Tedarikçi seçim probleminin incelendiği bir diğer literatür taraması çalışmasında Ho vd. (2010), 2000-2008 yılların arasında yayımlanmış çalışmaları ele almışlardır. Çalışmada hangi yöntemlerin yaygın kullanıldı̆̆ı, hangi seçim kriterleri üzerinde durulduğu ve yöntemlerin yetersiz kaldığı yönler nelerdir sorularına yanıt aranmıştır.

Wu ve Barnes (2011), 2001-2011 yılları arasında yapılan çalışmaları incelediklerin çalışmalarında tedarikçi seçiminde kullanılan yöntemleri tanıttıktan sonra yöntemleri tekil ve entegre yaklaşımlar olarak 2 grupta sınıflamışlardır. 2000-2010 yılları arasında yayınlanmış 170 yayının incelendiği çalışmada Setak vd. (2012), tedarikçi seçim sürecini ÇNKV yöntemler, matematik programlama modelleri, yapay zekâ yöntemleri ölçeğinde ele almışlardır. Çalışmada ayrıca matematik programlama çözüm yaklaşımları alt başlıklar düzeyinde incelenmiştir. 
Ware vd. (2012) ise çalı̧̧malarında literatürde 1991-2011 yılları arasında yapılmış tedarikçi seçimi uygulamalarını inceleyerek yöntemleri sınıflamışlardır. Chai vd. (2013) ÇKKV, yapay zekâ ve matematik programlama sınıflaması altında 2008-2012 yılların arasında yayımlanmış 123 makaleyi inceleyerek 26 farklı yöntemi özetlemişlerdir. Govindan vd. (2013), yeşil tedarikçi seçimi üzerinde gerçekleştirdikleri literatür taramasında 1997-2011 yılları arasında yapılmış çalışmaları incelemişlerdir. Çalışma sonucunda bulanık teori ile entegre tekil yöntemlerin en sık kullanılan yöntemler olduğu bulgusunu elde etmişlerdir.

Özbek ve Eren (2013), tedarikçi seçim problemini üçüncü parti lojistik (3PL) tedarikçisi ölçeğinde ele alan yayınları inceledikleri çalışmalarında 2001-2012 yılları arasında yayınlanmış 70 çalışmayı kullanılan değerlendirme yöntemlerine göre sınıflandırılmışlardır.

\section{YÖNTEMLER}

\subsection{Bulanık Analitik Hiyerarşi Prosesi (BAHP)}

Analitik Hiyeraşi Prosesi (AHP), Thomas L. Saaty (1980) tarafından geliştirilmiş bir ÇKKV yöntemidir. AHP, karmaşık karar verme problemlerini amaç, ana kriterler, alt kriterler ve alternatiflerden oluşan hiyerarşik bir yapıda düzenleyerek, karar alternatif ve kriterlerine ikili karşılaştırmalar yoluyla göreceli önem değerleri atamak suretiyle karar mekanizmasının çalıştırılması esasına dayanmaktadır (Timor, 2011; Küçük ve Ecer, 2008). İnsan beyninin birden çok kriterden oluşan karar verme problemlerinde karar verme esnasında seçenek ve kriterleri ikili karşılaştırmalarla (pairwise comparisons) değerlendirdiği bilgisinden hareketle geliştirilmiştir (Ös, 2010). AHP'de kullanılan ikili karşılaştırmalar prosesi ile karar vericilerin karar problemine ilişkin deneyimleri, uzmanlıkları, bilgileri, algıları ve sezgileri gibi soyut kavramlar sayısallaştırarak karar sürecine dahil edilmektedir (Raharjo vd., 2009, Yı1maz, 2010). $\mathrm{Bu}$ çerçevede AHP'nin karar sürecine karar vericinin objektif ve subjektif düşüncelerini yansıtmasına olanak tanıması, yöntemin en önemli özelliği olarak kabul edilmektedir (Girginer, 2008; Sipahi ve Or, 2005).

AHP, birçok gerçek hayat karar probleminin çözümünde etkin bir biçimde kullanılmasına rağmen, ikili karşılaştırmalar sürecinde subjektif değerlendirmeler kesin sayılardan oluşan bir ölçek kullanmasından dolayı (Dağdeviren, 2007) ayrıca kesin olmama yani belirsizliğin hâkim olduğu karar süreçlerini incelemede yetersiz kaldığı için eleştirilmektedir.

Belirsizlik durumunda etkin karar verme konusundaki sayılan eksik yönlerin giderilmesi maksadıyla AHP yaklaşımının bulanık mantık entegrasyonu ile modellenen Bulanık AHP (BAHP) yaklaşımı olarak kullanılması önerilmiştir. Dolayısıyla BAHP yaklaşımı, AHP sürecinin, bulanık mantık ve dilsel değişkenlerin kullanımı ile birleştirmiş bir problem çözme tekniğine dönüştürülmüş halidir (Bali ve Gencer, 2005). BAHP yaklaşımında karar vericiler ikili karşılaştırmalar sürecinde bulanık sayıları veya dilsel değişkenleri kullanarak daha rahat ve daha etkin değerlendirmeler yapabilmektedir (Özgörmüş vd., 2005).

BAHP yöntemi kullanılarak karar problemlerinin çözümü için farklı araştırmacılar tarafindan farklı yaklaşımlar önerilmiştir.

İkili karşılaştırmalar sürecinde Van Laarhoven ve Pedrycz (1983) tarafından yayınlanmış bulanık sayıların kullanıldığı ilk çalışmayı izleyen yıllarda ikili karşılaştırmalar sürecinde bulanık sayıları kullanan birçok çalışma izlemiştir.

Van Laarhoven ve Pedrycz (1983) tarafından önerilen yöntemde, klasik AHP yöntemi üçgen bulanık sayılar kullanarak modellenmiştir. Çalışmada bulanık ağırlıkları ve skorları elde 
etmek için Lootsma (1981) en küçük kareler yöntemini kullanılmıştır. Bu yaklaşımda ağırlıkların elde edilmesinde klasik AHP yaklaşımı işlemleri takip edilmektedir (Demirel vd., 2008).

BAHP için önerilen bir diğer yaklaşımda Buckley (1985), bulanık kıyas oranları kullanarak klasik AHP yöntemini bulanık ortamda modelleyerek, çözüm önerisi geliştirmiştir (Tolga ve Kahraman, 2009). Çalışmada bulanık ağırlık ve performans değerlerini hesaplamak üzere bulanık ortamlarda kolay genişletilebilmesi ve karşılaştırma matrislerinde tek bir çözüm elde edilmesini sağlaması bakımından geometrik ortalama metodundan faydalanılmıştır. Buckley (1985) yaklaşımında, karar problemi sürecinde değerlendirmeler üçgen bulanık sayılar yerine yamuk bulanık sayılar kullanılarak yapılmaktadır.

Cheng (1996) ise çalışmasında Shannon entropisinden yararlanarak, entropi ağırlığına dayalı bir BAHP çözüm yöntemi geliştirmiş ve bu yöntemi deniz taktik füze sistemlerinin değerlendirilmesinde kullanmıştır. Cheng tarafindan önerilen yöntemde bulanık standartlar oluşturulduktan sonra üyelik fonksiyonları kullanılarak performans skorları elde edilmektedir. Çok fazla hesaplama işlemi gerektirmediğinden diğer yöntemlere göre avantaj sağlamaktadır (Cheng, 1996).

BAHP ile karar problemlerinin çözümünde yukarıda sayılan yaklaşımların haricinde literatürde Chang (1996) tarafindan önerilen Mertebe Analizi Yöntemi ve bu yöntemin Liou ve Wang (1992b) tarafından önerilen Toplam Entegral Değer Yöntemi ile bütünleşik kullanıldığı yaklaşımlar bulunmaktadır. Bu çalışmada BAHP ile yapılan modellemelerde bu iki yöntem baz alındığı için bu yöntemler izleyen başlıklarda detaylı olarak incelenmektedir.

\subsubsection{Mertebe Analizi Yöntemi}

Chang (1996) tarafından önerilen Mertebe Analizi Yöntemi literatürde Genişletilmiş Analiz Yöntemi ismi ile de anılmaktadır.

$$
X=\left\{x_{1}, x_{2}, \ldots, x_{n}\right\} \text { bir kriter kümesi ve } U=\left\{u_{1}, u_{2}, \ldots, u_{n}\right\} \text { bir hedef kümesi olmak }
$$

üzere, Chang'ın mertebe analizi yöntemine göre, her bir kriter alınarak her bir hedef için mertebe analizi uygulanmaktadır. Böylece her bir ölçüt için $\mathrm{m}$ adet mertebe analiz değeri elde edilmektedir. Elde edilen mertebe analizi değerleri,

$$
M_{g_{i}}^{1}, M_{g_{i}}^{2}, \ldots, M_{g_{i}}^{m}, \quad i=1,2, \ldots, n
$$

şeklinde ifade edilir.

Chang'ın genişletilmiş analizi kullanılarak karar problemi aşağıdaki adımlar izlenerek çözülür (Chang, 1996):

Adım 1. $i$. kritere göre bulanık sentetik mertebe değeri,

$$
S_{i}=\sum_{j=1}^{m} M_{g_{i}}^{j} \otimes\left[\sum_{i=1}^{n} \sum_{j=1}^{m} M_{g_{i}}^{j}\right]^{-1}
$$

Eşitliği kullanılarak hesaplanır. Eşitlik açılarak,

$$
\sum_{j=1}^{m} M_{g_{i}}^{j}=\left(\sum_{j=1}^{m} l_{j}, \sum_{j=1}^{m} m_{j}, \sum_{j=1}^{m} u_{j}\right)
$$




$$
\begin{gathered}
\sum_{i=1}^{n} \sum_{j=1}^{m} M_{g_{i}}^{j}=\left(\sum_{i=1}^{n} l_{i}, \sum_{i=1}^{n} m_{i}, \sum_{i=1}^{n} u_{i}\right) \\
{\left[\sum_{i=1}^{n} \sum_{j=1}^{m} M_{g_{i}}^{j}\right]^{-1}=\left(\frac{1}{\sum_{i=1}^{n} u_{i}}, \frac{1}{\sum_{i=1}^{n} m_{i}}, \frac{1}{\sum_{i=1}^{n} l_{i}},\right.}
\end{gathered}
$$

eşitlikleri elde edilir.

Adım 2. $M_{1},\left(l_{1}, m_{1}, u_{1}\right)$ parametreleri ile; $M_{2},\left(l_{2}, m_{2}, u_{2}\right)$ parametreleri ile gösterilmek üzere, $M_{1}=\left(l_{1}, m_{1}, u_{1}\right) \leq M_{2}=\left(l_{2}, m_{2}, u_{2}\right)$ ifadesinin olasilik derecesi,

$$
V\left(M_{2} \geq M_{1}\right)=\sup _{y \geq x}\left[\min \left(\mu_{M_{1}}(x), \mu_{M_{2}}(y)\right)\right]
$$

eşitliği ile tanımlanır. $M_{1}$ ve $M_{2}$ üçgensel konveks bulanık sayılar olmak üzere,

$$
V\left(M_{2} \geq M_{1}\right)=\operatorname{hgt}\left(M_{1} \cap M_{2}\right)=\mu_{M_{2}}(d)=\left\{\begin{array}{cc}
1 & m_{2} \geq m_{1} \\
0 & , \quad l_{1} \geq u_{2} \\
\frac{l_{1}-u_{2}}{\left(m_{2}-u_{2}\right)-\left(m_{1}-l_{1}\right)} & , \text { diğer durumlar }
\end{array}\right.
$$

eşitliği elde edilir. $V\left(M_{2} \geq M_{1}\right)$ ifadesi $M_{1}$ ve $M_{2}$ ÜBS'larının kesişim kümesinin ordinatı olan üyelik fonksiyonu değerine tekabül etmek üzere Şekil 1.'de gösterilmiştir.

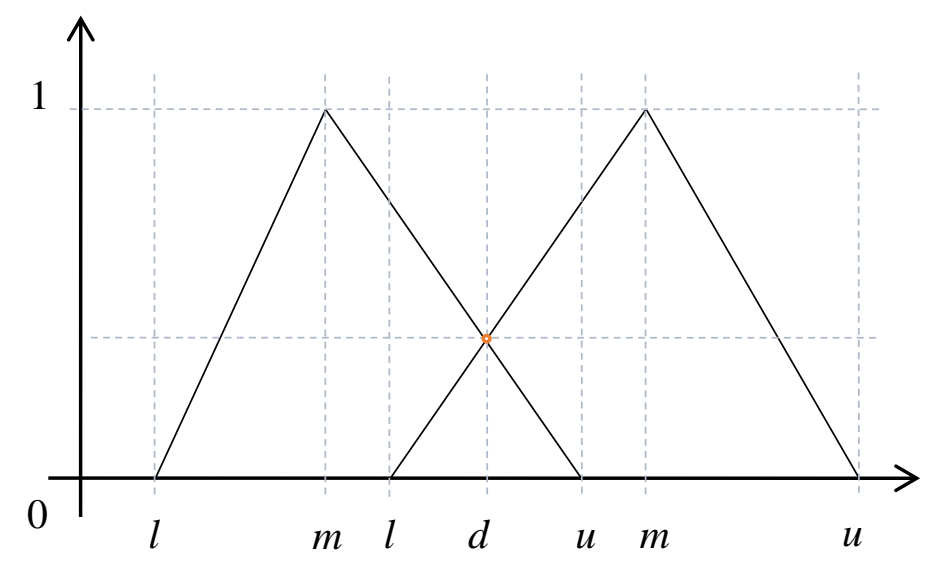

Şekil 1: M1 ve M2 Üçgensel Bulanık Sayılarının Kesişimi

$M_{1}$ ve $M_{2}$ üçgensel bulanık sayılarının kıyaslanabilmesi için $V\left(M_{2} \geq M_{1}\right)$ ve $V\left(M_{1} \geq M_{2}\right)$ değerlerinin her ikisinin de hesaplanması gerekmektedir.

Adım 3. Konveks bir M bulanık sayısının $k$ adet $M_{i} i=\{1,2, \ldots, k\}$ bulanık sayılarından büyük olmasinın olabilirlik derecesi, 


$$
\begin{aligned}
& =V\left(M \geq M_{1}, M_{2}, \ldots, M_{k}\right) \\
& =V\left[\left(M \geq M_{1}\right),\left(M \geq M_{2}\right), \ldots,\left(M \geq M_{k}\right)\right] \\
& =\min V\left(M \geq M_{i}\right), i=1,2, \ldots, k
\end{aligned}
$$

eşitlikleri ile tanımlanabilir. Burada $i=\{1,2, \ldots, k\} \quad$ için $\quad d^{\prime}\left(A_{i}\right)=\min V\left(S_{i} \geq S_{k}\right)$ $k \neq i$ olmak üzere ağırlık vektörü,

$$
W^{\prime}=\left(d^{\prime}\left(A_{1}\right), d^{\prime}\left(A_{2}\right), \ldots, d^{\prime}\left(A_{n}\right)\right)^{T} i=\{1,2, \ldots, n\}
$$

Adım 4. Üçüncü adımda elde edilen $W^{\prime}$ vektörü normalize edilerek gerçek sayılardan oluşan,

$$
W=\left(d\left(A_{1}\right), d\left(A_{2}\right), \ldots, d\left(A_{n}\right)\right)^{T} i=\{1,2, \ldots, n\}
$$

vektörü elde edilir.

\subsubsection{Toplam Entegral Değer Analizi}

Bulanık değerlerin sıralanmasında kullanılan yöntemlerden biri olan ve Liou ve Wang (1992) tarafından geliştirilmiş olan Toplam Entegral Değer Yönteminde $\alpha \in[0,1]$ iyimserlik endeksi olmak üzere $\tilde{A}=(l, m, u)$ şeklinde verilen üçgensel bulanık sayılar için toplam entegral değer hesaplanarak sıralamalar yapılmaktadır. Toplam Entegral Değer yönteminde kullanılan $\alpha \in[0,1]$ iyimserlik endeksi, karar vericinin iyimserlik düzeyini göstermektedir. Tanımdan hareketle $\alpha$ değeri 1'e yaklaştıkça iyimser bir karar vericiden, 0 'a yaklaştığında ise karamsar bir karar vericiden bahsedilebilir (Sofyalıoğlu, 2009).

$\alpha \in[0,1]$ iyimserlik endeksi olmak üzere $\tilde{A}=(l, m, u)$ şeklinde verilen üçgensel bulanık sayılar için toplam entegral değer,

$$
I_{T}^{\alpha}(\tilde{A})=\frac{1}{2} \alpha(m+u)+\frac{1}{2}(1-\alpha)(l+m)
$$

şeklinde hesaplanmaktadır. $\tilde{A}_{i}$ ve $\tilde{A}_{j}$ bulanık sayıları için,

$$
\begin{aligned}
& I_{T}^{\alpha}\left(\tilde{A}_{i}\right)<I_{T}^{\alpha}\left(\tilde{A}_{j}\right) \text { ise } \tilde{A}_{i}<\tilde{A}_{j} \\
& I_{T}^{\alpha}\left(\tilde{A}_{i}\right)=I_{T}^{\alpha}\left(\tilde{A}_{j}\right) \text { ise } \tilde{A}_{i}=\tilde{A}_{j} \\
& I_{T}^{\alpha}\left(\tilde{A}_{i}\right)>I_{T}^{\alpha}\left(\tilde{A}_{j}\right) \text { ise } \tilde{A}_{i}>\tilde{A}_{j}
\end{aligned}
$$

eşitsizlikleri kullanılarak bulanık değerler sıralanmaktadır (Kaptanoğlu ve Özok, 2006).

\subsubsection{Toplam Entegral Değer Analizinin Mertebe Analizi ile Bütünleşik Kullanımı}

Liou ve Wang (1992) tarafından önerilen yöntemin, mertebe analizi yöntemine bütünleşik kullanılması, mertebe analiz yönteminde takip edilen ikinci adımdan sonra bulanık sayıların Toplam Entegral Değer Analiz ile sıralanması esasına dayanmaktadır (Göksu ve 
Güngör, 2008). Mertebe Analizi yöntemi ile elde edilen $S_{i}$ bulanık sentetik mertebe değeri, karar verici ya da araştırmacı tarafından belirlenen bir iyimserlik düzeyinde Eşitlik (9)'da kullanılarak gerçekleştirilmektedir.

Bulanık sentetik mertebe değeri $S_{i}=\left(l_{i}, m_{i}, u_{i}\right)$ ve $i=1,2, \ldots, n$ olmak üzere, toplam entegral değer,

$$
\begin{aligned}
I_{T}^{\alpha}\left(S_{i}\right) & =\frac{1}{2} \cdot \alpha\left(m_{i}+u_{i}\right)+\frac{1}{2} \cdot(1-\alpha)\left(l_{i}+m_{i}\right) \\
& =\frac{1}{2} \cdot\left(\alpha u_{i}+m_{i}+(1-\alpha) l_{i}\right) \\
& =w_{i}
\end{aligned}
$$

eşitliği yardımıyla hesaplanır. Eşitlik kullanılarak elde edilen ağırlık vektörü $W^{\prime}=\left(w_{1}, w_{2}, \ldots, w_{n}\right)^{T}$, normalize edilerek,

$$
W=\left(\frac{w_{1}}{\sum_{i=1}^{n} w_{i}}, \frac{w_{2}}{\sum_{i=1}^{n} w_{i}}, \ldots, \frac{w_{n}}{\sum_{i=1}^{n} w_{i}}\right)
$$

gerçek sayılardan oluşan göreli önem vektörü bulunur.

\subsection{COmplex PRoportional ASsesment (COPRAS)}

COPRAS (COmplex PRoportional ASsesment - Kompleks Oransal Değerlendirme Karmaşı1k Nispi Değerlendirme), Çok Kriterli Karar Verme problemlerinde alternatiflerin önem fayda dereceleri bakımından adım adım değerlendirmek üzere geliştirilmiş bir yöntemdir. 2006 yılında Kaklaus vd. tarafından yürütülmekte olan bir Avrupa Birliği projesi kapsamında kullanılmıştır. $\mathrm{Bu}$ çalışmada Vilnius Gediminas Teknik Üniversitesi'nin ana binasının pencereleri, düşük yayınımlı 1s1 kontrol (Low-E) kaplamalı camlarla üretilen pencereler ile değiştirilmiş, en iyi alternatifin belirlenmesinde COPRAS yöntemi kullanılmıştır (Kaklauskas vd., 2006).

COPRAS Yöntemi, matematiksel hesaplamalarının kolaylığı, basit bir yaklaşımla değerlendirme yapabilmesi ve paket program gereksinimi bulunmaması nedeniyle literatürde çok çeşitli karar problemlerine başarı ile uygulanmıştır.

COPRAS yöntemi kullanılarak bir ÇKKV probleminde yer alan alternatiflerin değerlendirilmesinde 7 adımdan oluşan bir hesaplama yapılmaktadır. Söz konusu adımlar aşağ1da özetlenmiştir (Chatterjee vd., 2011):

\section{Adım 1. Karar matrisinin oluşturulması}

Tüm ÇKKV yöntemlerinde olduğu gibi COPRAS yönteminin de ilk adım karar problemine ait bir karar matrisinin oluşturulmasıdır.

$m$ adet alternatif ve $n$ adet kriterin bulunduğu bir karar probleminde $x_{i j} i$. alternatifin $j$. kritere göre performans değerini göstermek üzere $X$ karar matrisi, 


$$
X=\left[x_{i j}\right]_{m x n}=\left[\begin{array}{cccc}
x_{11} & x_{12} & \mathrm{~K} & x_{1 n} \\
x_{12} & x_{22} & \mathrm{~K} & x_{2 n} \\
\mathrm{M} & \mathrm{O} & \mathrm{O} & \mathrm{M} \\
x_{m 1} & x_{m 2} & \mathrm{~K} & x_{m n}
\end{array}\right] \quad i=1,2, \ldots, m \quad j=1,2, \ldots, n
$$

eşitliği ile gösterilir.

\section{Adım 2. Normalizasyon ve normalize karar matrisinin oluşturulması}

Normalizasyon işlemi, karar probleminde kullanılan performans değerlerinden oluşan serilerin farklı ölçeklerde değerlendirilmesinden ve farklı birimlerden oluşmasından dolayı verilerin aynı birime dönüştürülmesini böylece serilerin karşılaştırılabilir olmasını sağlamaktadır. Ayrıca, serinin çok geniş aralıklarda değerler aldığı durumlarda da verilerin daha küçük aralıklara çekilmesi için de normalizasyon işlemi yapılmaktadır (Yıldırım, 2014). COPRAS yönteminde normalize işleminde kriterin fayda ya da maliyet özelliği taşıması önem arz etmemektedir.

COPRAS yönteminde $X$ karar matrisini oluşturan $x_{i j}$ performans değerleri,

$$
\bar{x}_{i j}=\frac{x_{i j}}{\sum_{i=1}^{m} x_{i j}}
$$

eşitliği kullanılarak normalize performans değerlerine dönüştürülür, böylece $\bar{X}$ normalize karar matrisi,

$$
\bar{X}=\left[\bar{x}_{i j}\right]_{m x n}=\left[\begin{array}{cccc}
\bar{x}_{11} & \bar{x}_{12} & \mathrm{~K} & \bar{x}_{1 n} \\
\bar{x}_{12} & \bar{x}_{22} & \mathrm{~K} & \bar{x}_{2 n} \\
\mathrm{M} & \mathrm{O} & \mathrm{O} & \mathrm{M} \\
\bar{x}_{m 1} & \bar{x}_{m 2} & \mathrm{~K} & \bar{x}_{m n}
\end{array}\right] \quad i=1,2, \ldots, m \quad j=1,2, \ldots, n
$$

eşitliği ile gösterilir.

\section{Adım 3. Ă̆ırlıklandırma ve ağırlıklı normalize karar matrisinin oluşturulması}

Karar probleminde alternatiflerin değerlendirilmesinde kriterlerin karara ne oranda etki edeceğini belirlemek üzere kriter ağırlıklarından faydalanılmaktadır. $w_{j}, j$. kriterin ağırlığını göstermek üzere, ağırlıklar toplamı 1'e eşit olan oransal önem derecelerini ifade etmektedir.

$\bar{X}$ normalize karar matrisini oluşturan $\bar{x}_{i j}$ normalize performans değerleri,

$$
\hat{x}_{i j}=\bar{x}_{i j} \cdot w_{j}
$$

eşitliği kullanılarak $\hat{x}_{i j}$ ağırlıklı normalize performans değerlerine dönüştürülür, bu işlem sonunda $\hat{X}$ ağırlıklı normalize karar matrisi,

$$
\hat{X}=\left[\hat{x}_{i j}\right]_{m x n}=\left[\begin{array}{cccc}
\hat{x}_{11} & \hat{x}_{12} & \mathrm{~K} & \hat{x}_{1 n} \\
\hat{x}_{12} & \hat{x}_{22} & \mathrm{~K} & \hat{x}_{2 n} \\
\mathrm{M} & \mathrm{O} & \mathrm{O} & \mathrm{M} \\
\hat{x}_{m 1} & \hat{x}_{m 2} & \mathrm{~K} & \hat{x}_{m n}
\end{array}\right] \quad i=1,2, \ldots, m \quad j=1,2, \ldots, n
$$


eşitliği ile gösterilir. Normalize performans değerleri ağırlıklandırıldıktan sonra her bir kriter için, alternatiflerin ağırlıklı performans değerleri toplamı, ilgili kriterin ağırlık değerine, $\hat{X}$ ağırlıklı normalize karar matrisini oluşturan tüm $\hat{x}_{i j}$ 'lerin toplamı ise 1'e eşit olur.

Adım 4. Fayda ve maliyet ölçütlerini baz alan toplam ă̆ırlıklı normalize değerlerin hesaplanmast

Karar probleminde alternatifleri değerlendirmek üzere seçilmiş olan kriterlerin ölçütleri farklılık arz etmektedir. Alternatiflerin kritere göre aldıkları performans değerlerinin daha büyük olması alternatifin daha çok tercih edilmesini sağlıyorsa, kriterin fayda özelliği, daha küçük olması alternatifin daha çok tercih edilmesini sağlıyorsa kriterin maliyet özelliği gösterdiği söylenebilir. Kriterin fayda ya da maliyet özelliği göstermesi bakımından ölçüt bazlı toplam ağırlıklı normalize değerler, $S_{+i}$ fayda ölçütleri toplamını, $S_{-i}$ ise maliyet ölçütleri toplamını göstermek üzere,

$$
\begin{gathered}
S_{+i}=\sum_{j=1}^{k} \hat{x}_{+i j} i=1,2, \ldots, m j=1,2, . ., k \\
S_{-i}=\sum_{j=k+1}^{n} \hat{x}_{-i j} i=1,2, \ldots, m j=k+1, k+2, \ldots, n
\end{gathered}
$$

eşitlikleri kullanılarak hesaplanır. Eşitliklerde yer alan $\hat{x}_{+i j}$ ve $\hat{x}_{-i j}$ ağırlıklı normalize performans değerleri sırasıyla, fayda ve maliyet ölçütlerine sahip performans değerlerini ifade etmektedir.

Adım 5. Göreceli önem değerlerinin hesaplanması

Bir önceki adımda elde edilen $S_{+i}$ ve $S_{-i}$ değerleri her bir alternatifin karar probleminde hedeflenen amaca ne derecede ulaştı̆̆ının bir göstergesidir. $S_{+i}$ ve $S_{-i}$ parametreleri kullanılarak hesaplanacak $Q_{i}$ değeri $i$. alternatifin göreceli önem değerini göstermek üzere,

$$
Q_{i}=S_{+i}+\frac{S_{-\min } \cdot \sum_{i=1}^{m} S_{-i}}{S_{-i} \cdot \sum_{i=1}^{m}\left(\frac{S_{-\min }}{S_{-i}}\right)} \quad i=1,2, \ldots, m
$$

eşitliği kullanılarak belirlenir. Eşitlikte yer alan $S_{-\min }$ parametresi, $S_{-i}$ değerlerinden en küçük (minimum) olanını ifade etmektedir.

Hesaplanan $Q_{i}$ değeri ne kadar büyük ise temsil ettiği alternatif o oranda idealdir.

Adım 6. Performans indeksi değerlerinin hesaplanması

$Q_{i}$ değeri ile direkt ilişki içerisinde olan performans indeksi, alternatiflerin göreli önem değerinin ideal alternatif ile karşılaştırılması için kullanılmaktadır. $P_{i}, i$. alternatifin performans indeksi değerini göstermek üzere,

$$
P_{i}=\left[\frac{Q_{i}}{Q_{\max }}\right] \cdot 100 \% \quad i=1,2, \ldots, m
$$

eşitliği kullanılarak hesaplanmaktadır. Eşitlikten de görüleceği üzere yüzdesel bir oran olan performans indeksi değeri en ideal alternatif $100 \%$ olmak üzere $0 \%-100 \%$ aralığında değerler almaktadır. 


\section{Adım 7. Alternatiflerin değerlendirilmesi}

Tüm hesaplama adımlarının ardından elde edilen $P_{i}$ değerleri büyükten küçüğe doğru siralanarak alternatiflerin tercih sıralaması elde edilir.

\subsubsection{Bulanık COPRAS (COPRAS-F)}

Karar problemlerinin doğası gereği bünyesinde barındırdığı belirsizlik, etkin karar almanın önünde engel teşkil etmektedir. Bulanık küme, sayı ve sistemlerin karar alma sürecinde karşılaşılan belirsizliği gidermek üzere çeşitli Çok Kriterli Karar Verme yöntemleri ile bütünleşik olarak kullanıldığ birçok çalışma literatürde kabul görmüştür. COPRAS yönteminde de belirsizlikten doğan etkin karar alamama durumunun üstesinden gelmek üzere bulanık mantık entegresyonu ile tasarlanan COPRAS-F yöntemi formunda kullanılması mümkündür. COPRASF yönteminde bulanık sayılardan oluşan performans değerleri kullanılmaktadır. Karar probleminin niteliği bakımından subjektif değerlendirmeler içerdiği durumlarda etkin karar alınmasına olanak sağlayan COPRAS-F yöntemi dilsel ölçeklerden faydalanmaktadır. COPRASF yönteminde COPRAS yöntemi adımları temel alınarak bulanık sayılar ile işlem yapılmaktadır. Yöntemin işleyişinde üçgensel ya da yamuksal bulanık sayılar kullanılabilmektedir. Bu çalışmada COPRAS-F yöntemi üçgensel bulanık sayılar ile kullanılacağından yamuksal bulanık sayılar ile işlem süreci adımları ele alınmamıştır. Yamuksal bulanık sayıların kullanıldığı COPRAS-F yöntemi hakkında bilgi edinmek için Nourianfar ve Montazer (2013) çalışmaları incelenebilir.

COPRAS-F yönteminde izlenen adımlar aşağıdaki gibidir (Fouladgar vd., 2012):

\section{Adım 1. Bulanık karar matrisinin oluşturulması}

$m$ adet alternatifin ve $n$ adet kriterin yer aldığı bir karar probleminde $\mathscr{F}_{i} i$. alternatifin, $j$. kritere göre değerlendirilmesinden elde edilen bulanık performans değerini ifade etmektedir. $\mathscr{X}_{\overparen{I}}$ üçgensel bulanık sayısı,

$$
\mathscr{S}_{i j}=\left(x_{i j}^{l}, x_{i j}^{m}, x_{i j}^{u}\right)
$$

parametrelerinden oluşmaktadır. $\mathscr{K}_{i j}$ bulanık performans değerlerin oluşan $\mathbb{X}^{\circ}$ karar matrisi,

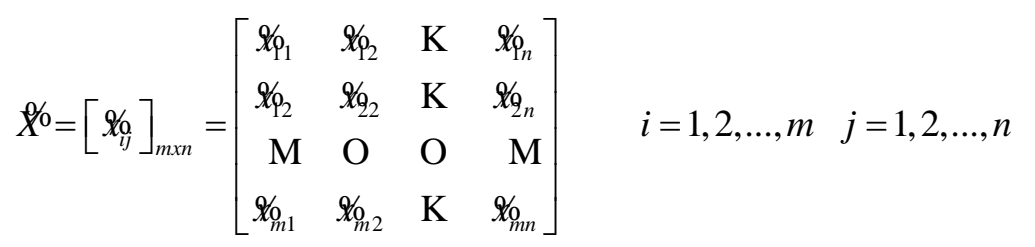

şeklinde gösterilir.

COPRAS-F yönteminde karar matrisi oluşturulurken birden fazla karar verici olmas1 durumunda, karar vericilerin kararları tek bir grup kararına dönüştürülmektedir. $K$ karar verici sayısını göstermek üzere $k$. karar vericinin $i$. alternatifi $j$. kritere göre değerlendirmesinden elde edilen performans değeri $\mathscr{B}_{i j k}=\left(x_{i j k}^{l}, x_{i j k}^{m}, x_{i j k}^{u}\right)$ üçgensel bulanık sayısı ile gösterilir ve $\mathscr{X}_{i j}$ indirgenmiş grup performans değerine ait parametreler,

$$
x_{i j}^{l}=\min _{k}\left\{x_{i j k}^{l}\right\}
$$




$$
\begin{gathered}
x_{i j}^{m}=\frac{1}{K} \sum_{k=1}^{K} x_{i j k}^{m} \\
x_{i j}^{u}=\max _{k}\left\{x_{i j k}^{u}\right\}
\end{gathered}
$$

eşitlikleri kullanılarak hesaplanır.

\section{Adım 2. Bulanık karar matrisinin durulaştırılması ve karar matrisinin oluşturulması}

Bir önceki adımda elde edilen bulanık karar matrisini oluşturan bulanık sayılar kesin sayılara dönüştürülerek karar matrisi hesaplanan kesin değerlerden hareketle oluşturulur. Bulanık sayıların dönüştürülmesinde basitliği ve işlem kolaylığı açısından sıklıkla Best Nonfuzzy Performance (BNP) faydalandığı görülmektedir. COPRAS-F yöntemi de bulanık sayıları kesin sayıları dönüştürmede BNP yönteminden faydalanmaktadır. BNP yöntemi ile dönüştürüme işlemi,

$$
x_{i j}=\frac{\left[\left(x_{i j}^{u}-x_{i j}^{l}\right)+\left(x_{i j}^{m}-x_{i j}^{l}\right)\right]}{3}+x_{i j}^{l}
$$

eşitliği kullanılarak yapılmaktadır. Kesin sayılara dönüştürülen $x_{i j}$ performans değerleri ile oluşturulan $X$ karar matrisi,

$$
X=\left[x_{i j}\right]_{m x n}=\left[\begin{array}{cccc}
x_{11} & x_{12} & \mathrm{~K} & x_{1 n} \\
x_{12} & x_{22} & \mathrm{~K} & x_{2 n} \\
\mathrm{M} & \mathrm{O} & \mathrm{O} & \mathrm{M} \\
x_{m 1} & x_{m 2} & \mathrm{~K} & x_{m n}
\end{array}\right] \quad i=1,2, \ldots, m \quad j=1,2, \ldots, n
$$

eşitliği ile gösterilir.

\section{Adım 3. COPRAS adımlarının takip edilmesi}

COPRAS-F yönteminde durulaştırma sonucu elde edilen $X$ karar matrisini oluşturan $x_{i j}$ performans değerleri, Eşitlik (18)-(25) takip edilerek analiz edilir ve elde edilen $P_{i}$ değerleri büyükten küçüğe doğru sıralanarak alternatiflerin tercih sıralaması elde edilir.

\subsubsection{Gri COPRAS (COPRAS-G)}

COPRAS-G yönteminde COPRAS yönteminden farklı olarak kesin (crisp) sayılar yerine aralık (interval) olarak ifade edilmiş gri sayılar kullanılmaktadır. Alternatiflerin kritere göre aldıkları performans değerleri net bir şekilde ifade edilemediği, aralık olarak ifade edildiği karar problemlerinin çözümünde COPRAS-G yöntemi kullanılmaktadır. Sayıların siyahtan beyaza doğru yöneldiği bir ölçek üzerinden ifade edildiği Gri Teori, az bilgiye sahip olunmas1 durumunda matematiksel işlemler yapılmasına olanak sağlamaktadır. COPRAS yönteminin Gri Teori ile bütünleşik kullanımı ile geliştirilen COPRAS-G yönteminde de karar vericinin sahip olduğu az bilgi ile etkin kararlar alması amaçlanmaktadır. COPRAS-G yöntemi temelde COPRAS yöntemi ile aynı adımları takip etmektedir (Zavadkas vd., 2008):

\section{Adım 1. Karar matrisinin oluşturulması}

COPRAS yönteminde karar matrisini oluşturan $x_{i j}$ kesin değerleri, COPRAS-G yönteminde aralık değerleri ifade eden $\otimes x_{i j}$ gri sayıları ile oluşturulmaktadır. $\otimes x_{i j}$ gri sayısı, $i$. alternatifin $j$. kritere göre aldığı gri performans değerini göstermek üzere $\underline{x}_{i j}$ alt limiti ve $\bar{x}_{i j}$ üst 
limite sahip bir aralığ ifade etmektedir. $m$ adet alternatifin $n$ adet kriterden elde ettiği $\otimes x_{i j}$ gri performans değerleri kullanılarak oluşturulan $\otimes X$ karar matrisi,

$$
\begin{gathered}
\otimes X=\left[\left[\otimes x_{i j}\right]\right]_{m \times n}=\left[\begin{array}{cccc}
{\left[\otimes x_{11}\right]} & {\left[\otimes x_{12}\right]} & \mathrm{K} & {\left[\otimes x_{1 n}\right]} \\
{\left[\otimes x_{21}\right]} & {\left[\otimes x_{22}\right]} & \mathrm{K} & {\left[\otimes x_{2 n}\right]} \\
\mathrm{M} & \mathrm{M} & \mathrm{O} & \mathrm{M} \\
{\left[\otimes x_{m 1}\right]} & {\left[\otimes x_{m 2}\right]} & \mathrm{L} & {\left[\otimes x_{m n}\right]}
\end{array}\right] \quad i=1,2, \ldots, m \quad j=1,2, \ldots, n \\
\otimes X=\left[\left[\underline{x}_{i j} ; \bar{x}_{i j}\right]\right]_{m \times n}=\left[\begin{array}{cccc}
{\left[\underline{x}_{11} ; \bar{x}_{11}\right]} & {\left[\underline{x}_{12} ; \bar{x}_{12}\right]} & \mathrm{K} & {\left[\underline{x}_{1 n} ; \bar{x}_{1 n}\right]} \\
{\left[\underline{x}_{21} ; \bar{x}_{21}\right]} & {\left[\underline{x}_{22} ; \bar{x}_{22}\right]} & \mathrm{K} & {\left[\underline{x}_{2 n} ; \bar{x}_{2 n}\right]} \\
\mathrm{M} & \mathrm{M} & \mathrm{O} & \mathrm{M} \\
{\left[\underline{x}_{m 1} ; \bar{x}_{m 1}\right]} & {\left[\underline{x}_{m 2} ; \bar{x}_{m 2}\right]} & \mathrm{L} & {\left[\underline{x}_{m n} ; \bar{x}_{m n}\right]}
\end{array}\right] \quad i=1,2, \ldots, m \quad j=1,2, \ldots, n
\end{gathered}
$$

eşitlikleri ile gösterilir. Burada $i$. alternatifin $j$. kritere göre aldığı gri performans değerinin $\underline{x}_{i j}$ alt limiti, en küçük değeri; $\bar{x}_{i j}$ üst limiti ise en büyük değeri ifade etmektedir.

COPRAS-G yönteminde kullanılan dilsel değerlendirmeler ve gri sayı karşı1ıkları $n$ karar verici sayısını göstermek üzere aşağıdaki eşitlikler kullanılarak geometrik ortalama yöntemi ile hesaplanarak tek bir grup kararına dönüştürülmektedir.

$$
\begin{aligned}
& \underline{a}_{l}=\left(\underline{a}_{l 1} \cdot \underline{a}_{l 2} \cdot \underline{a}_{l 3}, \mathrm{~K}, \cdot \underline{a}_{l n}\right)^{1 / n} \\
& \bar{a}_{u}=\left(\bar{a}_{u 1} \cdot \bar{a}_{u 2} \cdot \bar{a}_{u 3}, \mathrm{~K}, \cdot \bar{a}_{u n}\right)^{1 / n}
\end{aligned}
$$

Adım 2. Normalizasyon ve normalize karar matrisinin oluşturulması

COPRAS-G yönteminin normalizasyon adımında $\otimes X$ karar matrisini oluşturan $\otimes x_{i j}$ gri performans değerlerinin $\underline{x}_{i j}$ alt limiti ve $\bar{x}_{i j}$ üst limiti için ayrı ayrı normalizasyon işlemi yapılır. $\underline{\tilde{x}}_{i j}$ normalize alt limiti, $\tilde{\bar{x}}_{i j}$ ise normalize üst limiti göstermek üzere $\otimes \mathscr{R}_{i j}$ normalize performans değerlerinin limitleri,

$$
\begin{aligned}
& \underline{\mathscr{P}}_{i j}=\frac{\underline{x}_{i j}}{\frac{1}{2}\left(\sum_{i=1}^{m} \underline{x}_{i j}+\sum_{i=1}^{m} \bar{x}_{i j}\right)}=\frac{2 \underline{x}_{i j}}{\sum_{i=1}^{m} \underline{x}_{i j}+\sum_{i=1}^{m} \bar{x}_{i j}} \\
& \underline{x}_{i j}^{o}=\frac{\bar{x}_{i j}}{\frac{1}{2}\left(\sum_{i=1}^{m} \underline{x}_{i j}+\sum_{i=1}^{m} \bar{x}_{i j}\right)}=\frac{2 \bar{x}_{i j}}{\sum_{i=1}^{m}\left(\underline{x}_{i j}+\bar{x}_{i j}\right)}
\end{aligned}
$$

eşitlikleri kullanılarak hesaplanır ve $\otimes \mathbb{X}^{\circ}$ normalize karar matrisi,

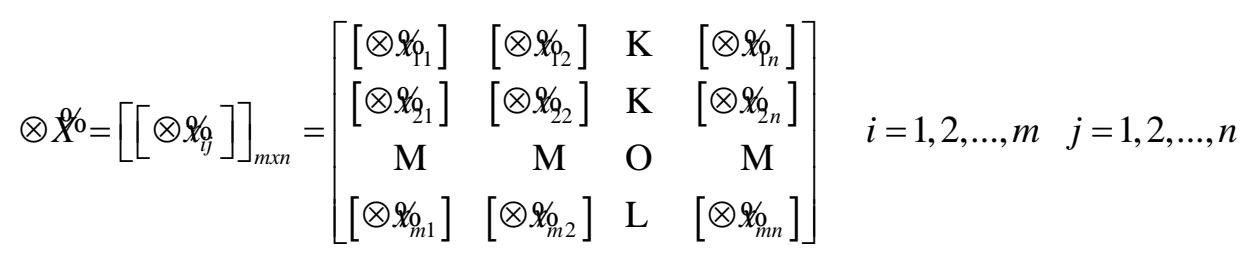




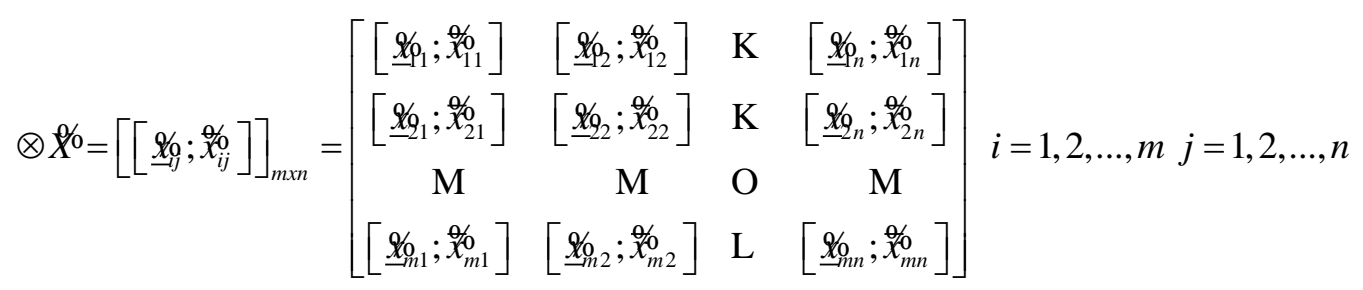

şeklinde gösterilir.

Adım 3. Ăgırlıklandırma ve ă̆ırlıklı normalize karar matrisinin oluşturulması

COPRAS-G yönteminde normalizasyon adımında olduğu gibi ağırlıklandırma adımında da $\otimes \mathscr{F}_{i j}$ normalize gri performans değerlerinin $\underline{\mathscr{Z}}_{i j}$ normalize alt limiti ve $\tilde{\bar{x}}_{i j}$ normalize üst limiti için ayrı ayrı işlemler yapılmaktadır.

$w_{j}, j$. kriterin karar problemindeki önem derecesini (ağırlığını), $\underline{\hat{x}}_{i j}$ ağırlıklı alt limiti, $\hat{\bar{x}}_{i j}$ ise ağırlıklı üst limiti göstermek üzere $\otimes \hat{x}_{i j}$ ağılıklı normalize performans değerlerinin limitleri,

$$
\begin{aligned}
& \hat{\underline{x}}_{i j}=\underline{\mathscr{X}}_{i j} \cdot w_{j} \\
& \hat{\bar{x}}_{i j}=\widetilde{X}_{i j}^{o} \cdot w_{j}
\end{aligned}
$$

eşitlikleri kullanılarak hesaplanır ve $\otimes \hat{X}$ ağılıklı normalize karar matrisi,

$$
\begin{aligned}
& \otimes \hat{X}=\left[\left[\otimes \hat{x}_{i j}\right]\right]_{m x n}=\left[\begin{array}{cccc}
{\left[\otimes \hat{x}_{11}\right]} & {\left[\otimes \hat{x}_{12}\right]} & \mathrm{K} & {\left[\otimes \hat{x}_{1 n}\right]} \\
{\left[\otimes \hat{x}_{21}\right]} & {\left[\otimes \hat{x}_{22}\right]} & \mathrm{K} & {\left[\otimes \hat{x}_{2 n}\right]} \\
\mathrm{M} & \mathrm{M} & \mathrm{O} & \mathrm{M} \\
{\left[\otimes \hat{x}_{m 1}\right]} & {\left[\otimes \hat{x}_{m 2}\right]} & \mathrm{L} & {\left[\otimes \hat{x}_{m n}\right]}
\end{array}\right] \quad i=1,2, \ldots, m \quad j=1,2, \ldots, n \\
& \otimes \hat{X}=\left[\left[\hat{x}_{i j} ; \hat{\bar{x}}_{i j}\right]\right]_{m x n}=\left[\begin{array}{cccc}
{\left[\underline{\hat{x}}_{11} ; \hat{\bar{x}}_{11}\right]} & {\left[\hat{\underline{x}}_{12} ; \hat{\bar{x}}_{12}\right]} & \mathrm{K} & {\left[\hat{\underline{x}}_{1 n} ; \hat{\bar{x}}_{1 n}\right]} \\
{\left[\hat{\underline{x}}_{21} ; \hat{\bar{x}}_{21}\right]} & {\left[\hat{\underline{x}}_{22} ; \hat{\bar{x}}_{22}\right]} & \mathrm{K} & {\left[\hat{\underline{x}}_{2 n} ; \hat{\bar{x}}_{2 n}\right]} \\
\mathrm{M} & \mathrm{M} & \mathrm{O} & \mathrm{M} \\
{\left[\hat{x}_{m 1} ; \hat{\bar{x}}_{m 1}\right]} & {\left[\hat{\underline{x}}_{m 2} ; \hat{\bar{x}}_{m 2}\right]} & \mathrm{L} & {\left[\hat{\underline{x}}_{m n} ; \hat{\bar{x}}_{m n}\right]}
\end{array}\right] i=1,2, \ldots, m j=1,2, \ldots, n
\end{aligned}
$$

şeklinde gösterilir.

Adım 4. Fayda ve maliyet ölçütlerini baz alan toplam ă̆ırlıklı normalize değerlerin hesaplanmast

Karar probleminde alternatiflerin değerlendirilmesinde kullanılan kriterlerin fayda ya da maliyet özelliği göstermesi bakımından ölçüt bazlı toplam ağırlıklı normalize değerler, $S_{+i}$ fayda ölçütleri toplamını, $S_{-i}$ ise maliyet ölçütleri toplamını göstermek üzere,

$$
\begin{gathered}
S_{+i}=\frac{1}{2} \sum_{j=1}^{k}\left(\underline{\hat{x}}_{i j}+\hat{\bar{x}}_{i j}\right) \quad i=1,2, \ldots, m j=1,2, \ldots, k \\
S_{-i}=\frac{1}{2} \sum_{j=k+1}^{n}\left(\hat{\hat{x}}_{i j}+\hat{\bar{x}}_{i j}\right) i=1,2, \ldots, m j=k+1, k+2, \ldots, n
\end{gathered}
$$


eşitlikleri yardımıyla hesaplanır. Böylece $\otimes \hat{x}_{i j}$ ağırlıklı normalize performans değerleri beyazlaştırılarak kesin sayıya dönüştürülür.

\section{Adım 5. COPRAS adımlarının takip edilmesi}

COPRAS-G yönteminde göreceli önem ve performans indeksi değerleri COPRAS yönteminde olduğu gibi Eşitlik (24)-(25) kullanılarak hesaplanmaktadır. Elde edilen $P_{i}$ değerleri büyükten küçüğe doğru sıralanarak alternatiflerin tercih sıralaması elde edilir. Daha yüksek $P_{i}$ değeri alternatifin daha fazla tercih edilebilir olmasını sağlamaktadır.

\section{5. ÇOK KRİTERLİ TEDARIKÇİ SEÇIMM MODELİ: OTOMOTIV SEKTÖRÜNDE TEDARIKKÇİ SEÇIMI UYGULAMASI}

Otomotiv sektöründe tedarik zinciri yönetimi operasyonel mükemmelliği sağlamak üzere yürütülen faaliyetlerin bütünü olarak düşünüldügünde oldukça zor bir süreçtir. Diğer tüm sektörlerde olduğu gibi otomotiv sektöründe de yeni pazarlara girmek, küresel boyutta faaliyet göstermek, operasyonel mükemmelliğe erişmek, efektif ve düşük maliyet ile üretim yapmak tedarik zinciri yönetimini çok önemli bir konu olarak şirket politikaları arasında öncelikli bir pozisyonda tutmaktadır.

$\mathrm{Bu}$ çalışmada otomotiv sektöründe faaliyet gösteren bir işletme tarafindan minibüs, midibüs ve 12 metre üstü otobüslerde kullanılmak üzere üretimi yapılan klima sistemi için tedarikçi seçimi problemi modellenmiştir. İşletme tarafından bu ürün için kompozit malzemeden üretilmiş alt tablalar tedarik edilmektedir. Tedarik edilen alt tabla üzerine klima sistemi komponentleri monte edilerek klima sistemleri nihai halini almaktadır. Bu bağlamda çalışma kapsamında incelenen karar problemi tek kaynaktan (tedarikçiden) tek ürün tedarik edilmesi formunda tanımlanmıştır.

Karar verici kişi ya da kişilerin belirlenebilmesi maksadıyla şirket ile yüz yüze görüşme yapılmıştır. Şirket politikaları uyarınca tedarik süreci ile ilgili işlemleri yürüten satın alma departmanı çalışanlarından 5 kişilik karar verici grubu oluşturulmuştur. Karar verici grubun üyeleri satın alma departmanında, satın alma elemanı, satın alma sorumlusu ve proje satın alma sorumlusu olarak görev yapmaktadırlar. Grup üyelerinin sektör tecrübeleri 9-22 yıl arasında değişiklik göstermekte iken işletme bünyesinde 1-15 yıl arası görev yaptıkları bilinmektedir. Karar verici grup satın alma konusunda uzmanlaşmış çalışanlardan oluştuğu için çalışma kapsamında uzman görüşlerinden faydalanılmak suretiyle analizler yapılmıştır.

Çalışma kapsamında karar verici grup belirlendikten sonra grup üyeleri ile yapılan yüz yüze görüşmede literatür taraması kapsamında belirlenmiş olan kriterler sunulmuştur. Karar verici uzman grubu tarafindan belirlenen kriterler, Noorul Haq ve Kannan (2006) tarafindan önerilen kriter setine temel alınarak literatüre paralellik arz edecek şekilde güncellenerek bu çalışmada kullanılmıştır.

Dilsel ölçek kullanılarak değerlendirmeye uygun olan kriter seti 7 ana, 15 alt kriterden oluşmaktadır.

Çalışma kapsamında kullanılacak kriterler, karar probleminin analiz safhasında tablolar üzerinde daha etkin kullanılmak üzere kodlanmıştır. Bir bütün olarak kriter setini oluşturan ana kriterler ile alt kriterler, karşılık gelen kısaltma kodları ile Tablo 1.'de gösterilmiştir. 
Tablo 1: Tedarikçi Seçiminde Kullanılan Kriter ve Alt Kriterler

\begin{tabular}{|c|c|c|c|}
\hline \multicolumn{2}{|c|}{ Kısaltma Kodu } & \multirow[t]{2}{*}{ Ana Kriter } & \multirow[t]{2}{*}{ Alt Kriter } \\
\hline K1 & & & \\
\hline & K11 & & Teslimat zamanına uyma \\
\hline & K12 & & Teslimat şartnamelerine uyma \\
\hline \multirow[t]{3}{*}{ K2 } & & Fiyat & \\
\hline & K21 & & Fiyat farkl111klar1 \\
\hline & K22 & & Miktar İndirimleri \\
\hline \multirow[t]{2}{*}{ K3 } & & Hizmet & \\
\hline & & & Müşteri hizmetleri \\
\hline \multirow[t]{5}{*}{ K4 } & & Tedarikçi İşletmenin genel yapısı & \\
\hline & K41 & & Personel Sayıs1 \\
\hline & K42 & & Referanslar \\
\hline & K43 & & Sektör Tecrübesi \\
\hline & K44 & & Tesis Yeri \\
\hline \multirow[t]{3}{*}{ K5 } & & Kalite & \\
\hline & K52 & & İade Oranı \\
\hline & K52 & & Kalite Sistemleri \\
\hline \multirow[t]{3}{*}{ K6 } & & Teknik Yetenekler ve Mühendislik & \\
\hline & K61 & & Teknik Bilgi Geliştirme \\
\hline & K62 & & Teknik Kapasite \\
\hline \multirow[t]{3}{*}{ K7 } & & Üretim Yetenekleri & \\
\hline & K71 & & Üretim Kapasitesi \\
\hline & K72 & & Üretim Miktarında Esneklik \\
\hline
\end{tabular}

Karar probleminde kullanılacak alternatif seti, işletmenin satın alma departmanı tarafindan belirlenmiştir. İşletme, ürün tedarik etme potansiyeli bulunan firmaları tedarikçi havuzuna alarak değerlendirmektedir. Bu doğrultuda firmanın klima sistemleri için kompozit alt tabla ürünü tedarik ettiği firma ve tedarik sürecinde alternatif olarak değerlendirebilecekleri 4 firmadan oluşan bir alternatif seti oluşturulmuştur.

Gerek işletmenin gerekse tedarikçi alternatifi işletmelerin ticari işlemleri ve bilgilerinin gizli tutulması amacıyla tedarikçi alternatiflerinin isimleri çalışmada açıkça belirtilmemiştir. Tedarikçi alternatifleri sırasıyla A1, A2, A3, A4 kısaltmaları ile kodlanmış ve yapılan tüm analizler ile sonuçların yorumlanmasında bu kodlamalar kullanılmıştır.

Çalışma kapsamında gerek kriterlerin ağırlıklandırılmasında gerekse alternatiflerin değerlendirilmesinde kullanılan yönteme ve kullanılan sayıların ait olduğu sistem teorilerine göre literatürde yer alan farklı dilsel değerlendirme ölçekleri kullanılmıştır. Kullanılan ölçekler ve sayı karşılıkları Tablo 2. ve 3.'te gösterilmiştir.

Tablo 2: Kriterlerin Ağırlıklandırılmasına Kullanılan Dilsel Değerlendirme Ölçek ve Say1 Karşılı̆g (Kaptanoğlu ve Özok, 2006)

\begin{tabular}{c|c} 
Ölçek değerleri & Ücgen Bulanık Sayı \\
\hline Tamamen Önemli & $(7,9,9)$ \\
Cok Kuvvetli Derecede Önemli & $(5,7,9)$ \\
Kuvvetli Derecede Önemli & $(3,5,7)$ \\
Biraz Önemli & $(1,3,5)$ \\
Eşit Önemli & $(1,1,1)$
\end{tabular}


Tablo 3: Alternatiflerin Değerlendirilmesinde Kullanılan Dilsel Değerlendirme Ölçekleri ve Sayı Karşılıkları

\begin{tabular}{c|c|c} 
Ölçek değerleri & Gri Sayı & Ücgen Bulanık Sayı \\
\hline Çok Kötü & {$[0,1]$} & $(0,0,1)$ \\
Kötü & {$[1,3]$} & $(0,1,3)$ \\
Biraz Kötü & {$[3,4]$} & $(1,3,5)$ \\
Ortalama & {$[4,5]$} & $(3,5,7)$ \\
Biraz İyi & {$[5,6]$} & $(5,7,9)$ \\
İyi & {$[6,9]$} & $(7,9,10)$ \\
Çok İyi & {$[9,10]$} & $(9,10,10)$ \\
& Sahu vd. (2012) & Chen $(2001)$
\end{tabular}

Çalışma kapsamında veri toplama aracı olarak LimeSurvey açık kaynak kodlu anket yazılımı, verilerin analizinde ise Microsoft Excel paket programı kullanılmıştır.

\subsection{Kriterlerin Önem Derecelerinin Belirlenmesi}

Çalışmada, tedarikçi seçiminden kullanılacak kriterlerin ağırlıklandırılmasında literatürde tedarikçi seçim problemlerinde başarılı ile uygulanmış olan Bulanık Analitik Hiyerarşi Prosesi yönteminden faydalanılmıştır. Bu yöntemin kullanılmasının nedeni, Klasik AHP yaklaşımından farklı olarak kesin sayılar yerine bulanık sayıların kullanılması ile karar verme sürecinde karşılaşılan belirsizliğin üstesinden gelinebilmesidir. BAHP uygulaması için literatüre dayandırılan dilsel ağırlıklandırma ölçeklerinden faydalanılmıştır. Klasik AHP'de kullanılan 1-9 ölçeği yerine karar vericilerin değerlendirmelerini "iyi, çok iyi, önemli, önemsiz" gibi sözel ifadeler kullanarak yapmaları karar vericilerin daha etkin ve kolay değerlendirmeler yapmasına olanak sağlamaktadır.

Literatürde Bulanık AHP yönteminin farklı yaklaşımlarda uygulandığı görülmektedir. Laarhoven ve Pedrycz (1983), Buckley (1985), Chang (1996), Cheng (1996), Liou ve Wang (1992) gibi bir çok araştırmacı tarafindan BAHP yaklaşımları mevcuttur. Bu çalışmada bu yaklaşımlar arasında en çok kullanılan ve Chang (1996) tarafından geliştirilmiş olan Mertebe Analizi Yöntemi temel alınmıştır. Mertebe Analizi Yöntemi algoritmasında kullanılan MIN operatörü bazı ana kriter ve alt kriterlerin ağırlıkların 0 (Sıfır) olarak hesaplanmasına neden olmaktadır. Bir karar probleminin hiyerarşik yapısı düşünüldüğünde bir ana kriterin bu yöntem kullanılarak ağırlığının 0 olarak hesaplanması durumunda bu ana kriterin altında yer alan alt kriterlerin yerel ağırlıkları ne olursa olsun global ağırlıklara çevrildiği durumda 0 değerine dönüşecektir. $\mathrm{Bu}$ dönüşüm karar vericinin değerlendirmelerinin tam olarak karar problemine yansımaması sorununu beraberinde getirdiği için Mertebe Analizi Yönteminin literatürde Liou ve Wang (1992) tarafından geliştirilen Toplam Entegral Değer Yöntemi ile bütünleşik kullanıldığı görülmektedir. Bu nedenle bu çalışmada Mertebe Analizi Yöntemi, Toplam Entegral Değer Yaklaşımı ile bütünleşik kullanıldığı bir yöntem ile kriter ağılıkları hesaplanmıştır.

Kriter ağırlıklarının belirlenmesi sürecinde ikili karşılaştırma değerlerinin tek bir grup karar değişkine dönüştürülmesinde $n$ karar verici sayısını göstermek üzere aşağıdaki eşitlikler kullanılarak geometrik ortalama hesaplanmıştır.

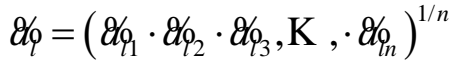

$$
\begin{aligned}
& \mathscr{Z}_{m}=\left(\mathscr{O}_{m 1} \cdot \mathscr{Z}_{{ }^{2}} \cdot \mathscr{B}_{m 3}, \mathrm{~K}, \mathscr{B}_{m n}\right)^{1 / n}
\end{aligned}
$$

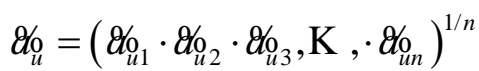


Hiyerarşik yapıda yer alan ana kriter ve alt kriterler için Eşitlik (46) kullanılarak geometrik ortalama yöntemi ile uzman grubun bireysel değerlendirmeleri tek bir grup kararına dönüştürülmüştür. Tablo 4.'te tek grup kararına indirgenmiş ana kriter değerlendirmeleri gösterilmiştir. ${ }^{1}$

Tablo 4: Tek Grup Kararına İndirgenmiş Ana Kriter Değerlendirmeleri

\begin{tabular}{|c|c|c|c|c|c|c|c|c|c|c|c|c|c|c|c|c|c|c|c|c|c|}
\hline \multirow{2}{*}{ K } & \multicolumn{3}{|c|}{ K1 } & \multicolumn{3}{|c|}{ K2 } & \multicolumn{3}{|c|}{$\mathbf{K} 3$} & \multicolumn{3}{|c|}{ K4 } & \multicolumn{3}{|c|}{ K5 } & \multicolumn{3}{|c|}{ K6 } & \multicolumn{3}{|c|}{ K7 } \\
\hline & $l$ & $m$ & $u$ & $l$ & & $u$ & $l$ & $m$ & $u$ & $l$ & $m$ & $u$ & $l$ & $m$ & $u$ & $l$ & $m$ & $u$ & $l$ & $m$ & $u$ \\
\hline K1 & 1,00 & 1,00 & 1,00 & 0,15 & 0,22 & 0,42 & 0,26 & 0,36 & 0,53 & 0,57 & 0,68 & 0,82 & 0,19 & 0,30 & 0,80 & 0,14 & 0,19 & 0,34 & 0,14 & 0,18 & 0,28 \\
\hline K2 & 2,41 & 4,51 & 6,54 & 1,00 & 1,00 & 1,00 & 1,29 & 1,78 & 2,41 & 0,44 & 0,72 & 1,25 & 0,24 & 0,34 & 0,64 & 0,37 & 0,49 & 0,69 & 0,23 & 0,38 & 0,71 \\
\hline K3 & 1,90 & 2,81 & 3,80 & 0,42 & 0,56 & 0,78 & 1,00 & 1,00 & 1,00 & 0,41 & 0,65 & 1,00 & 0,26 & 0,37 & 0,80 & 0,25 & 0,36 & 0,55 & 0,23 & 0,31 & 0,52 \\
\hline K4 & 1,23 & 1,48 & 1,75 & 0,80 & 1,38 & 2,29 & 1,00 & 1,53 & 2,45 & 1,00 & 1,00 & 1,00 & 0,23 & 0,32 & 0,58 & 0,30 & 0,44 & 0,64 & 0,41 & 0,53 & 0,72 \\
\hline K5 & 1,25 & 3,32 & 5,35 & 1,55 & 2,95 & 4,15 & 1,25 & 2,67 & 3,88 & 1,72 & 3,16 & 4,36 & 1,00 & 1,00 & 1,00 & 2,58 & 3,49 & 4,00 & 1,48 & 1,75 & 1,93 \\
\hline K6 & 2,95 & 5,16 & 7,24 & 1,45 & 2,04 & 2,71 & 1,81 & 2,81 & 4,00 & 1,55 & 2,26 & 3,38 & 0,25 & 0,29 & 0,39 & 1,00 & 1,00 & 1,00 & 0,20 & 0,25 & 0,35 \\
\hline K7 & 3,55 & 5,62 & 7,36 & 1,40 & 2,63 & 4,43 & 1,93 & 3,27 & 4,43 & 1,38 & 1,90 & 2,45 & 0,52 & 0,57 & 0,68 & 2,85 & 4,08 & 4,99 & 1,00 & 1,00 & 1,00 \\
\hline
\end{tabular}

Tablo 4.'te gösterilen veriler ikili karşılaştırmalar matrisi olarak işleme alınarak Bölüm 4.1.'de Bulanık AHP başlığı altında anlatılan adımlar takip edilerek analiz edilmiştir. Analiz sonucunda kriterlere ait hesaplanan yerel ve global ağırlıklar Tablo 5.'te gösterilmiştir.

Tablo 5: Mertebe Analizi Yönteminin Toplam Entegral Değer Yöntemi Üzerinde Kullanılmas1 İle Elde Edilen Kriter Önem Dereceleri

\begin{tabular}{|c|c|c|c|c|}
\hline \multirow[t]{2}{*}{ Ana Kriter } & \multirow[t]{2}{*}{ Alt Kriter } & \multirow[t]{2}{*}{$\begin{array}{l}\text { Ana Kriterin } \\
\text { Önceliği }\end{array}$} & $\begin{array}{c}\text { Alt Kriterin } \\
\text { Ana Kriter } \\
\text { İçerisinde } \\
\text { Önceliği }\end{array}$ & \multirow{2}{*}{$\begin{array}{c}\text { Alt Kriterin Ağırlığı } \\
\text { Global ağırlıklar } \\
\end{array}$} \\
\hline & & & Yerel ă̆ırlıklar & \\
\hline \multirow[t]{3}{*}{$\mathrm{K} 1$} & & 0,040 & & \\
\hline & K11 & & 0,602 & 0,024 \\
\hline & $\mathrm{K} 12$ & & 0,398 & 0,016 \\
\hline \multirow{3}{*}{$\mathrm{K} 2$} & & 0,123 & & \\
\hline & $\mathrm{K} 21$ & & 0,766 & 0,095 \\
\hline & $\mathrm{K} 22$ & & 0,234 & 0,029 \\
\hline \multirow[t]{2}{*}{$\mathrm{K} 3$} & & 0,081 & & \\
\hline & K31 & & 0,081 & 0,081 \\
\hline \multirow[t]{5}{*}{ K4 } & & 0,090 & & \\
\hline & K41 & & 0,086 & 0,008 \\
\hline & K42 & & 0,288 & 0,026 \\
\hline & K43 & & 0,379 & 0,034 \\
\hline & K44 & & 0,247 & 0,022 \\
\hline \multirow[t]{3}{*}{ K5 } & & 0,236 & & \\
\hline & K51 & & 0,432 & 0,102 \\
\hline & K52 & & 0,568 & 0,134 \\
\hline
\end{tabular}


K6

K7
K61

K62

K71

K72
0,182

0,604

0,110

$0,396 \quad 0,072$

0,247

0,261

0,739
0,065

0,183

Toplam Entegral Değer yönteminin Mertebe analizi ile bütünleşik kullanılması sonucunda elde edilen global kriter ağırlıkları yüzde cinsinden Şekil 2‘de gösterilmiştir.

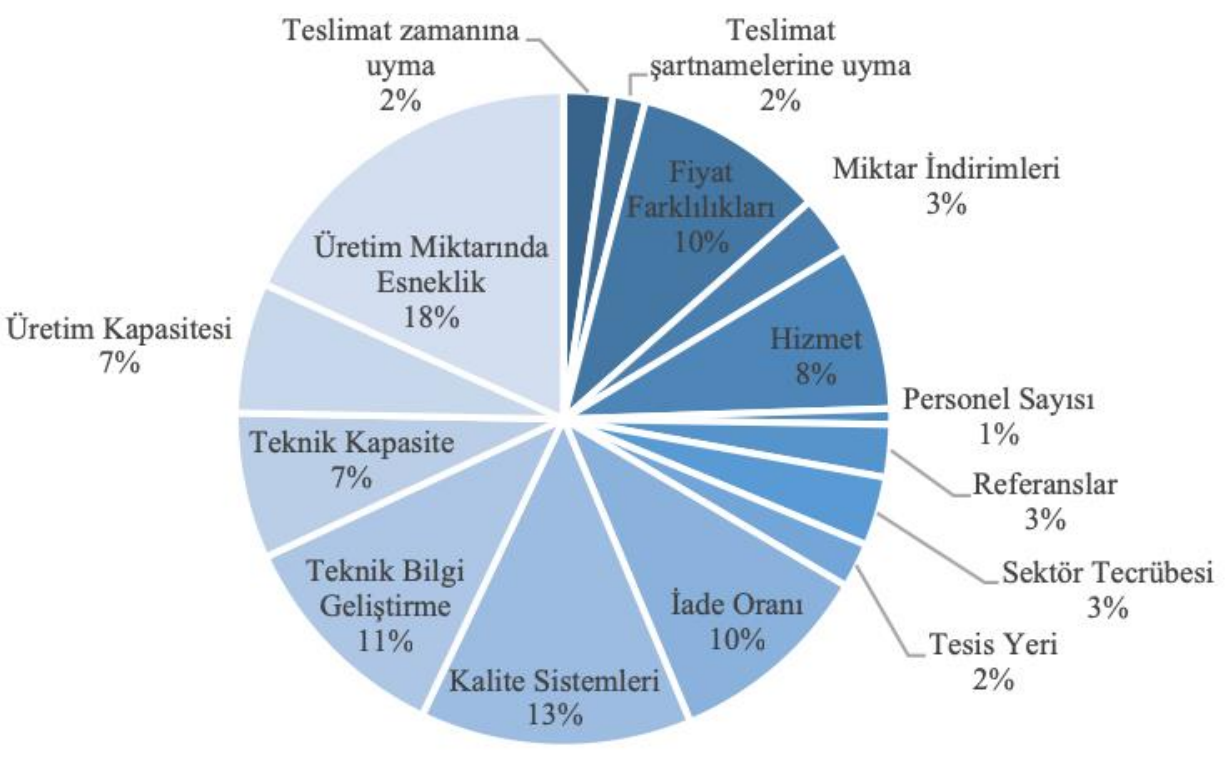

Şekil 2: Toplam Entegral Değer Yöntemi İle Mertebe Analizinin Bütünleşik Kullanımı İle Elde Edilen Global Kriter Önem Dereceleri

Analiz sonucunda işletmenin tedarikçi seçim sürecinde en çok önem verdiği kriter tedarikçi firmanın sahip olduğu üretim yetenekleri kriteri olmuştur. En az öneme sahip kriter ise dağıtım kriteri olmuştur. Toplam Entegral Değer yöntemine göre 4\% gibi düşük bir öneme sahip olduğu saptanan bu kriterin, Mertebe analizine göre ağırlığı $0 \%$ olarak bulunmuş̧tur.

\subsection{Tedarikçi Alternatiflerinin Değerlendirilmesi}

Karar probleminde yer alan tedarikçi alternatiflerinin değerlendirilmesinde Kaklaus vd. (2006) tarafindan önerilen COPRAS yöntemi esas alınmıştır. COPRAS yöntemi basit bir algoritma ile karmaşık hesaplamalar içermeksizin alternatiflerin değerlendirilmesine olanak sağlayan bir yaklaşımdır. Kesin sayılar ile uygulanmasının yanında sistem teorileri ile de eşanlı ve bütünleşik kullanılabilmektedir. Bir karar problemi içerisinde hem kesin hem bulanık hem de gri sayılar kullanılarak modellenebilmektedir.

$\mathrm{Bu}$ çalışmada tedarikçi seçim sürecinde tedarikçi alternatifleri COPRAS yöntemine bulanık sayıların entegre edilerek kullanıldığı COPRAS-F ve gri sayılar ile entegre modellendiği COPRAS-G yöntemleri aracılığıyla iki farklı şekilde değerlendirilmiştir. Hem COPRAS-F hem 
de COPRAS-G yöntemleri kullanılarak karar vericilerin değerlendirmelerinde dilsel değerlendirme ölçeklerine başvurulmuştur.

Karar problemine ilişkin tasarım süreci tamamlandıktan sonra, tasarlanan problem için veri toplama aşamasına geçilmiştir. Karar verici uzman grup 2 aşamalı bir değerlendirme sistemiyle başlangıçta kriterlerin önem derecelerini belirleyecek, ardından kriterlere göre tedarikçi alternatiflerini değerlendirecekleri için değerlendirme sürecinde kullanılmak üzere bir anket formu tasarlanmıştır.

Kriterler için ikili karşılaştırmalar esasına dayanan, alternatiflerin ise her bir kritere göre performansının değerlendirildiği anket formu LimeSurvey altyapısı kullanılarak çevrimiçi olarak tasarlanmıştır. Sorulara birden fazla yanıt verilmesi, soruların gözden kaçması, boş bırakılması gibi hataların önüne geçilmesi ve sonuçların bilgisayar ortamına aktarılmasını kolaylaştırması bakımından tercih edilen çevrimiçi form, karar verici grup üyeleri tarafından ayrı ayrı doldurulmuştur.

Karar vericinin tek bir kişi olmadığı yani bir grup kararının söz konusu olduğu karar problemi analizlerinde karar verici gruptan beyin firtınası yöntemi ile ortak bir grup beyanı şeklinde değerlendirme yapmaları, delphi tekniği kullanarak grup kararı verme ya da grup üyelerinin tekil değerlendirmelerinin çeşitli matematik işlemler ile birleştirilerek tek bir grup kararına dönüştürülmesi alternatifleri mevcuttur. Farklı görüşlerin daha açık ifade edilmesine ve diğer grup üyeleri ile etkileşimi minimize ederek daha özgün değerlendirmelere olan sağlaması bakımından bu çalışmada grup üyelerinin tekil değerlendirmeler yapması istenmiştir.

ÇKKV yöntemlerinde kriterlerin fayda ya da maliyet niteliği taşımasına göre farklı işlemler yapılmaktadır. Eğer kriter fayda özelliği gösteriyorsa kriterden alternatifin aldığı daha yüksek değerler amaca olumlu katkılar yapmakta iken, kriter maliyet özelliği taşıyorsa kritere göre alternatifin aldığı değerin düşük olması amaca olumlu katkı sağlamaktadır.

Karar probleminde yer alan kriter setleri niteliklerini belirlemek üzere incelendiğinde tüm kriterler için tedarikçi alternatiflerinin yüksek değerler almasının amaca olumlu katkılar sağlayacağı, yani tüm kriterlere göre performans skorlarının enbüyüklenmesinin bekleneceği belirlenmiştir.

Karar verici grup tarafından her bir kritere göre yapılan alternatiflerin değerlendirmeleri grup kararına dönüştürülerek bulanık karar matrisi $\mathbf{X}^{0}$ oluşturulmuştur. Bulanık karar matrisi Eşitlik (12) - (14) kullanılarak BNP yöntemi ile durulaştırılmış ve karar matrisi $X$ elde edilmiştir.

Tablo 6: Bulanık Karar Matrisi

\begin{tabular}{cccccccccccccc}
\hline $\mathbf{W}$ & $\mathbf{K}$ & & $\mathbf{A 1}$ & \multicolumn{1}{c}{$\mathbf{A 2}$} & & & $\mathbf{A 3}$ & & & $\mathbf{A 4}$ \\
\hline 0,024 & K11 & 4,83 & 6,88 & 8,74 & 4,83 & 6,88 & 8,74 & 5,52 & 7,61 & 9,12 & 5,91 & 8,00 & 9,31 \\
0,016 & K12 & 6,12 & 8,14 & 9,59 & 5,91 & 8,00 & 9,31 & 6,54 & 8,56 & 9,79 & 7,36 & 9,19 & 10,00 \\
0,095 & K21 & 5,81 & 7,77 & 9,12 & 6,21 & 8,17 & 9,31 & 7,61 & 9,12 & 9,79 & 4,66 & 7,02 & 8,52 \\
0,029 & K22 & 5,91 & 8,00 & 9,31 & 6,21 & 8,17 & 9,31 & 5,16 & 7,24 & 8,93 & 5,52 & 7,61 & 9,12 \\
0,081 & K31 & 5,16 & 7,24 & 8,93 & 4,15 & 6,53 & 8,35 & 5,52 & 7,61 & 9,12 & 6,21 & 8,17 & 9,31 \\
0,008 & K41 & 5,72 & 7,74 & 9,39 & 3,94 & 6,02 & 7,91 & 5,91 & 8,00 & 9,31 & 7,36 & 9,19 & 10,00 \\
0,026 & K42 & 6,88 & 8,74 & 9,79 & 6,54 & 8,56 & 9,79 & 6,12 & 8,14 & 9,59 & 7,61 & 9,12 & 9,79 \\
0,034 & K43 & 7,24 & 8,93 & 9,79 & 6,88 & 8,74 & 9,79 & 7,74 & 9,39 & 10,00 & 8,14 & 9,59 & 10,00 \\
0,022 & K44 & 7,74 & 9,39 & 10,00 & 6,54 & 8,56 & 9,79 & 0,00 & 0,00 & 3,32 & 0,00 & 3,50 & 5,81 \\
0,102 & K51 & 3,00 & 5,52 & 7,42 & 0,00 & 3,00 & 5,38 & 3,38 & 5,71 & 7,55 & 6,12 & 8,14 & 9,59 \\
0,134 & K52 & 4,74 & 7,22 & 8,71 & 4,43 & 6,87 & 8,52 & 6,54 & 8,56 & 9,79 & 7,74 & 9,39 & 10,00 \\
0,110 & K61 & 5,16 & 7,24 & 8,93 & 4,36 & 6,43 & 8,31 & 5,35 & 7,36 & 9,19 & 7,36 & 9,19 & 10,00 \\
0,072 & K62 & 6,54 & 8,56 & 9,79 & 4,66 & 6,77 & 8,49 & 6,54 & 8,56 & 9,79 & 7,00 & 9,00 & 10,00 \\
0,065 & K71 & 5,16 & 7,24 & 8,93 & 4,21 & 6,33 & 8,07 & 6,54 & 8,56 & 9,79 & 7,74 & 9,39 & 10,00 \\
0,183 & K72 & 5,52 & 7,61 & 9,12 & 7,24 & 8,93 & 9,79 & 0,00 & 2,95 & 5,16 & 0,00 & 3,88 & 6,21 \\
\hline
\end{tabular}


Gerçek sayılara dönüştürelen karar matrisi Eșitlik (2)-(9) hesaplamaları sonucunda elde edilen bulgular Tablo 7.'de özetlenmiş, Şekil 3'de görselleştirilmiştir.

Tablo 7: COPRAS-F Yöntemi Analiz Sonuçları

\begin{tabular}{ccccc}
\hline & $\boldsymbol{Q}_{\boldsymbol{i}}$ & $\boldsymbol{P}_{\boldsymbol{i}}$ & $\boldsymbol{\%}$ & Srra \\
\hline $\mathbf{A 1}$ & 0,252 & 0,959 & $96 \%$ & 2 \\
$\mathbf{A 2}$ & 0,248 & 0,945 & $94 \%$ & 3 \\
$\mathbf{A 3}$ & 0,237 & 0,900 & $90 \%$ & 4 \\
$\mathbf{A 4}$ & 0,263 & 1,000 & $100 \%$ & 1 \\
\hline
\end{tabular}

COPRAS-F yöntemi ile gerçekleştirilen analiz sonucu tedarikçi alternatifleri $A_{4} \mathrm{f} \quad A_{1} \mathrm{f} \quad A_{2} \mathrm{f} \quad A_{3}$ şeklinde siralanmıştır.

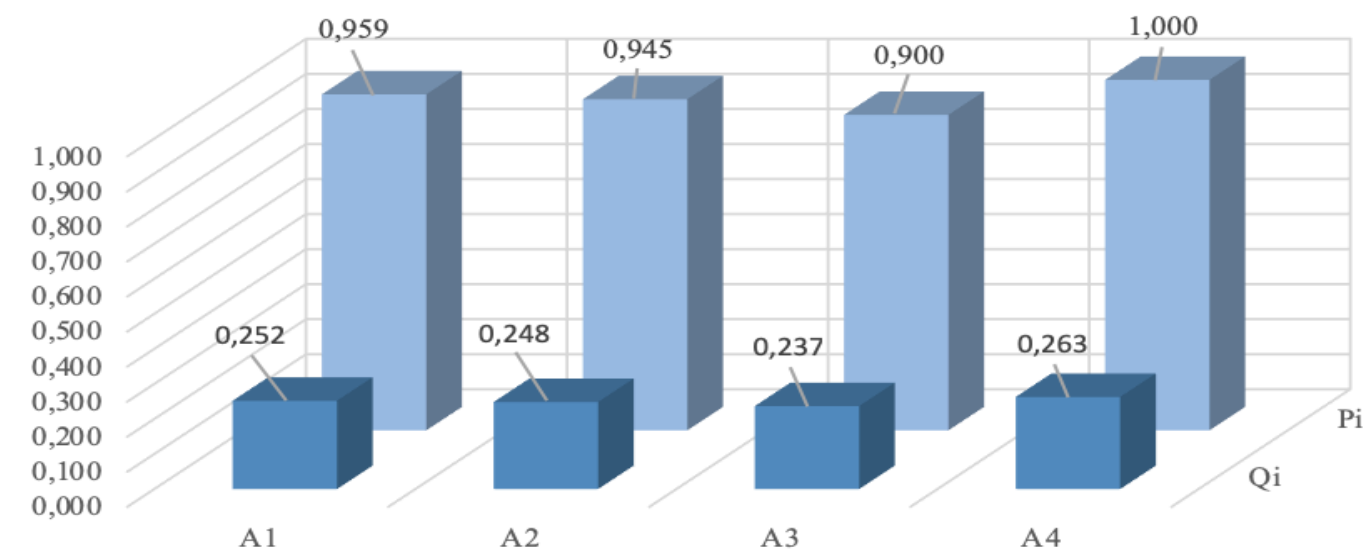

Şekil 3. COPRAS-F Yöntemi Sonuçlarına Göre Alternatif Sıralamaları

COPRAS-G yöntemi uygulanmak üzere karar vericilerin Tablo 3.'te yer alan ölçeğe göre dilsel değerlendirmeleri, gri sayı karşılıklarının indirgenmiş grup kararına dönüştürüldükten sonra matrise ağırlık ve kriter niteliklerinin eklenmesi ile $\otimes X$ gri karar matrisi elde edilmiştir.

Tablo 8. Gri Karar Matrisi

\begin{tabular}{cccccccccc}
\hline $\mathbf{W}$ & $\mathbf{K}$ & \multicolumn{3}{c}{$\mathbf{A 1}$} & \multicolumn{3}{c}{$\mathbf{A 2}$} & \multicolumn{3}{c}{$\mathbf{A 3}$} & \multicolumn{1}{c}{$\mathbf{A 4}$} \\
\hline 0,024 & $\mathrm{~K} 11$ & 4,96 & 6,27 & 4,96 & 6,27 & 5,33 & 7,38 & 5,53 & 8,00 \\
0,016 & $\mathrm{~K} 12$ & 5,58 & 7,65 & 5,53 & 8,00 & 5,79 & 8,30 & 6,51 & 9,19 \\
0,095 & $\mathrm{~K} 21$ & 5,79 & 7,54 & 6,00 & 8,17 & 7,38 & 8,84 & 5,46 & 7,21 \\
0,029 & $\mathrm{~K} 22$ & 5,53 & 8,00 & 6,00 & 8,17 & 5,14 & 6,80 & 5,33 & 7,38 \\
0,081 & $\mathrm{~K} 31$ & 5,14 & 6,80 & 4,86 & 6,51 & 5,33 & 7,38 & 6,00 & 8,17 \\
0,008 & $\mathrm{~K} 41$ & 5,38 & 7,06 & 4,54 & 5,83 & 5,53 & 8,00 & 6,51 & 9,19 \\
0,026 & $\mathrm{~K} 42$ & 6,27 & 8,48 & 5,79 & 8,30 & 5,58 & 7,65 & 7,38 & 8,84 \\
0,034 & $\mathrm{~K} 43$ & 6,80 & 8,66 & 6,27 & 8,48 & 7,06 & 9,39 & 7,65 & 9,59 \\
0,022 & $\mathrm{~K} 44$ & 7,06 & 9,39 & 5,79 & 8,30 & 0,00 & 2,93 & 2,99 & 4,48 \\
0,102 & $\mathrm{~K} 51$ & 4,38 & 6,00 & 2,55 & 4,93 & 4,44 & 6,05 & 5,58 & 7,65 \\
0,134 & $\mathrm{~K} 52$ & 5,22 & 7,65 & 5,04 & 7,06 & 5,79 & 8,30 & 7,06 & 9,39 \\
0,110 & $\mathrm{~K} 61$ & 5,14 & 6,80 & 4,74 & 6,05 & 5,19 & 6,51 & 6,51 & 9,19 \\
0,072 & $\mathrm{~K} 62$ & 5,79 & 8,30 & 4,92 & 6,56 & 5,79 & 8,30 & 6,00 & 9,00 \\
0,065 & $\mathrm{~K} 71$ & 5,14 & 6,80 & 4,70 & 6,33 & 5,79 & 8,30 & 7,06 & 9,39 \\
0,183 & $\mathrm{~K} 72$ & 5,33 & 7,38 & 6,80 & 8,66 & 2,70 & 4,13 & 3,17 & 4,68 \\
\hline
\end{tabular}


COPRAS-G yönteminin Eşitlik (35)-(45) hesaplamaları ile beyazlaştırılmış toplam ağırlıklı normalize değerler elde edilmiş ve her bir alternatife ait göreceli önem değerleri Qi hesaplanmıştır. İzleyen adımda Qi değerleri kullanılarak performans indeks değeri Pi'ler hesaplanarak alternatifler için sıralama oluşturulmuştur.

Tablo 9: COPRAS-G Yöntemi Analiz Sonuçları

\begin{tabular}{ccccc}
\hline & $\boldsymbol{Q}_{\boldsymbol{i}}$ & $\boldsymbol{P}_{\boldsymbol{i}}$ & $\boldsymbol{\%}$ & Sura \\
\hline $\mathbf{A 1}$ & 0,254 & 0,959 & $96 \%$ & 2 \\
$\mathbf{A 2}$ & 0,247 & 0,933 & $93 \%$ & 3 \\
$\mathbf{A 3}$ & 0,233 & 0,880 & $88 \%$ & 4 \\
$\mathbf{A 4}$ & 0,265 & 1,000 & $100 \%$ & 1 \\
\hline
\end{tabular}

COPRAS-G yöntemi ile gerçekleştirilen analiz sonucu tedarikçi alternatifleri $A_{4} \mathrm{f} \quad A_{1} \mathrm{f} \quad A_{2} \mathrm{f} \quad A_{3}$ şeklinde sıralanmıştır.

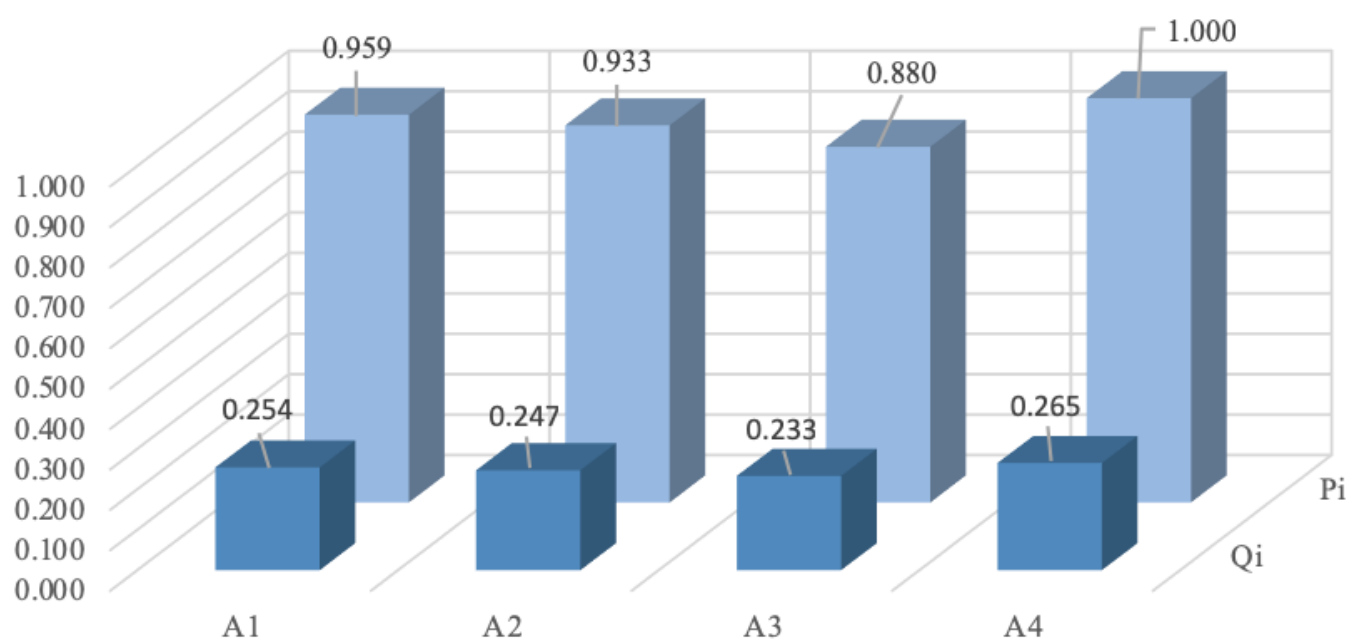

Şekil 4. COPRAS-G Yöntemi Sonuçlarına Göre Alternatif Sıralamaları

\section{SONUÇ}

$\mathrm{Bu}$ çalışmada otomotiv sektöründe faaliyet gösteren bir işletmenin tedarikçi seçim süreci incelenmiş, işletmenin önceliklerine göre belirlenen tedarikçi değerlendirme kriterleri ve tedarikçi alternatifleri bir karar problemi olarak modellenmiştir. Bu amaçla kriterlerin önem derecelerini belirlemek üzere BAHP yöntemi, tedarikçi alternatiflerini değerlendirmek üzere COPRAS-F ve COPRAS-G yöntemleri kullanılmıştır.

Analiz sonucunda işletmenin tedarikçi seçim sürecinde en çok önem verdiği kriter tedarikçi firmanın sahip olduğu üretim yetenekleri kriteri olmuştur. En az öneme sahip kriter ise dağıtım kriteri olmuştur. Toplam Entegral Değer yöntemine göre 4\% gibi düşük bir öneme sahip olduğu saptanan bu kriterin, Mertebe analizine göre ağırlığı $0 \%$ olarak bulunmuştur. 
Kriterlerin önem derecelerine göre siralaması $K 7 \mathrm{f} K 5 \mathrm{f} K 6 \mathrm{f} K 2 \mathrm{f} K 4 \mathrm{f} K 3 \mathrm{f} K 1$ şeklinde bulunmuştur. Ana kriter düzeyinde kriterlerin önem dereceleri ve sıralaması Şekil 5.'te gösterilmiştir.

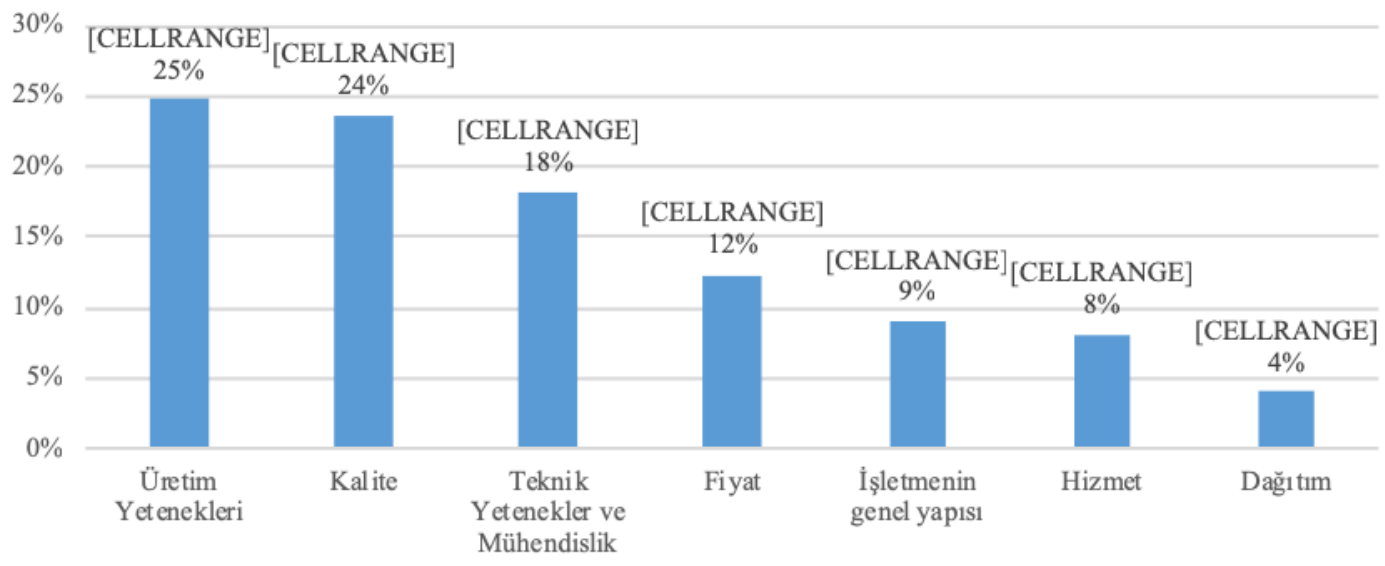

Şekil 5: Tedarikçi Seçim Ana Kriterlerinin Önem Dereceleri ve Sıralamas1

Şekil 5.'te özetlenen veriler incelendiğinde işletmenin tedarikçilerini üretim yeteneği, kalite ve teknik yetenek ve mühendislik yönünden daha ağırlıklı değerlendirdiği görülmektedir. Tedarik edilen ürünün kalitesini direkt olarak etkileyen bu faktörler, işletme için fiyattan daha çok önem arz etmektedir. Buradan işletmenin daha ucuzdan ziyade daha kaliteli ürün tedarik etme felsefesine sahip olduğu sonucu çıarılabilir.

Belirlenen kriter önem derecelerine göre alternatiflerin değerlendirilmesi sürecinde bulanık mantık ve gri teori COPRAS yöntemine entegre kullanılarak iki farklı analiz gerçekleştirilmiştir. Yöntemlerin karşılaştırılabilir olması ve elde edilen sonuçların nihai bir sıralamada birleştirilebilmesini sağlamak amacıyla homojen bir değerlendirmeye olanak sağlamak için yöntemler için aynı dilsel değerlendirme değişkenlerinden oluşan bir ölçek kullanılmıştır. Ölç̧ekte yer alan dilsel değerlendirme değişkenlerinin bulanık sayı karşılıkları kullanılarak COPRAS-F, gri sayı karşılıkları kullanılarak COPRAS-G yöntemi uygulanmıştır.

COPRAS yönteminde hesaplanan performans indeksi değerlerine $P_{i}$ göre tedarikçi alternatiflerinin skorları yöntemlere göre farklılık arz etmesine rağmen nihai sıralamalarda bir farklılık söz konusu değildir. Analiz sonuçlarına göre tedarikçi alternatiflerinin performans indeks değerleri ve sıralamaları Şekil 6.'da gösterilmiştir.

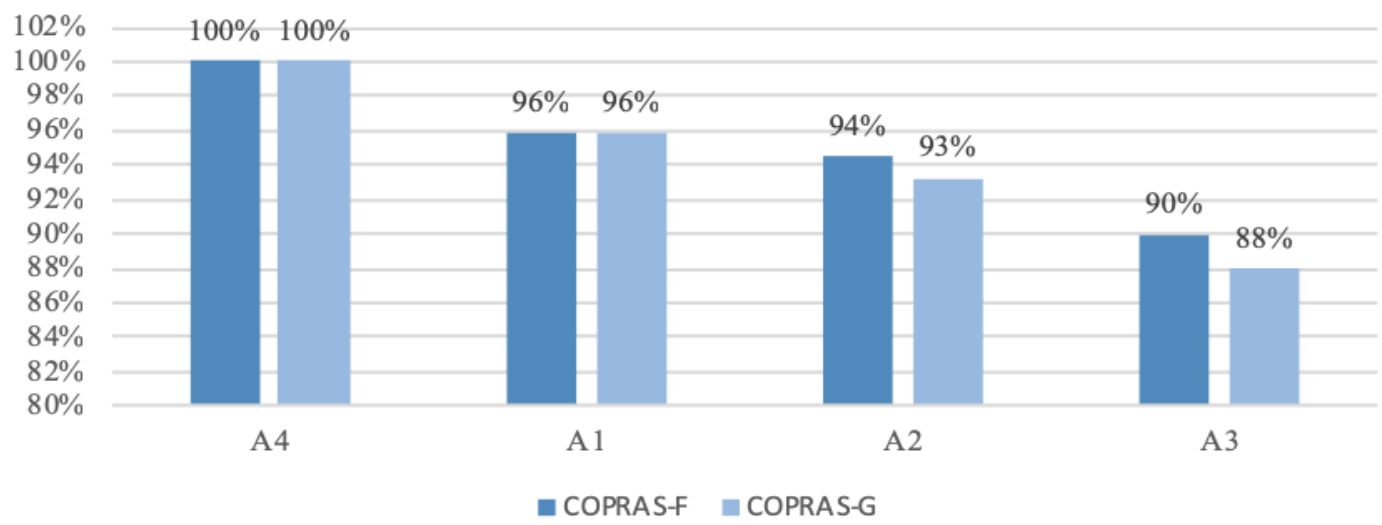

Şekil 6: Tedarikçi Alternatiflerinin Performans İndeks Değerleri ve Sıralamaları 
Şekil 6.'dan da görüleceği üzere işletmenin beklentilerine en uygun tedarikçi alternatifi A4 tedarikçisi olmuştur. Performans indeks değeri $100 \%$ olan tedarikçiyi sırasıyla A1 ve A2 tedarikçileri takip etmektedir. İşletmeye göre en düşük etkinliğe sahip tedarikçi A3 tedarikçisi olmuştur. A3 tedarikçisinin performans indeks değeri COPRAS-F yönteminde $90 \%$, COPRAS$\mathrm{G}$ yönteminde ise $88 \%$ olarak hesaplanmıştır. Yöntemler arası performans indeks değerleri arasında farklılık olmasının başlıca nedeni karar verici grubun kararlarının indirgenmiş tek bir grup kararı elde etme sürecinde izlenen farklı yaklaşımlar ve dilsel değerlendirme değişkenlerine karşılık gelen değerlerin ifade ettiği aralığın farklı olmasıdır.

$\mathrm{Bu}$ çalışmada tedarikçi alternatiflerinin değerlendirilmesinde bulanık ve gri sayılar ayrı ayrı modellemeler yapılarak kullanılmıştır. Karar vericilerin değerlendirmeleri bulanık ve gri dilsel değişkenlerin tanımlandığı ölçekler üzerinden sayısallaştırılmış ve analiz edilmiş̧ir. Karar verme sürecinin beraberinde getirdiği belirsizlik ve tam bilgiye sahip olmama durumu, literatürde bir çok araştırmacının etkin karar almak üzere farklı sistem teorilerini geliştirmelerine ve karar verme yöntemleri ile entegre kullanmalarına neden olmuştur. Gerek bulanık gerekse gri sistem teorisi eksik bilgi ve belirsizlik durumunun üstesinden gelmede etkin teoriler olarak kabul görmektedir. Sahip olunan bilgi düzeyinin temsili, bilginin sayısallaştırılması ve aritmetik operatörlerinin farklı olarak uygulanışı bakımından farklılık gösteren bu iki sistem teorisinin COPRAS yöntemi ile bütünleşik kullanıldığı bu çalışmada elde edilen sonuçlar incelendiğinde, analiz sonuçlarının tutarlı olduğu görülmektedir. Bu çalışmada her iki sistem teorisinin kıyaslanabilir olması amacıyla dilsel ölçekler üzerinden değerlendirmeler yapılmıştır. Dilsel değişken ölçeği 0-10 sayıları arasında sınırlanacak şekilde eş boyutlarda tercih edilmiştir. Sonuçlar incelendiğinde her iki model ile elde edilen tedarikçi sıralamalarını aynı olduğu, siralamada kullanılan performans indeksi değerlerinin ise farklı olmakla birlikte birbirine yakın olduğu görülmektedir. Kullanılan ölçekler her ne kadar eşit boyutlu olsa da ölçek değerlerinin aralıkları arasındaki farklılık ve kullanılan aritmetik operatörlerin farklı olması sonuçların farklı olmasına neden olmuştur. Genel olarak analiz sonuçları incelendiğinde sıralamanın esas alındığı karar problemlerinde kullandığı parametre sayısının az olması nedeniyle gri sayılar ile işlem yapılmasının daha kolay olduğu söylenebilir.

Sonuç olarak tedarikçi seçimi karar probleminde Bulanık AHP + COPRAS-F ve Bulanık AHP + COPRAS-G yöntemlerinin kolay ve hızlı sonuç ürettiği ve başarılı ile uygulanabileceği belirlenmiş olup, bu yöntemler benzer karar problemlerinde de kullanılabileceği gibi, çalışmada ele alınan tedarikçi seçim problemi farklı yöntemler ile çözülerek sonuçların karşılaştırılması mümkündür.

İzleyen çalışmalarda her iki sistem teorisinin bütünleşik olarak kullandığı bir karar matrisi üzerinden tekil bir analiz yapılabilir. Ayrıca Bulanık AHP yöntemi yerine ikili kıyaslamalar esasına dayalı ANP gibi yöntemler veya DEMATEL, Entropi vb. yaklaşımlar ile kriter önem dereceleri belirlenebilir. Bu çalışmada otomotiv sektöründe özellikle ticari araçlar sınıfi altında belirli niteliklere sahip bir alt sektör üzerinde tedarikçi seçimi problemi incelenmiştir. Yapılan analizler otomotiv sektörünün başka alt sektörlerinde tekrarlanarak kriter önem derecelerindeki değişimler incelenebilir. 


\section{KAYNAKÇA}

Aissaoui, N., Haouari, M., \& Hassini, E. (2007). Supplier selection and order lot sizing modeling: A review. Computers \& Operations Research, 34(12), 3516-3540.

Bali, Ö, Gencer, C . (2005). AHP, Bulanik AHP ve Bulanik Mantik’la Kara Harp Okuluna Öğretim Elemani Seçimi. Savunma Bilimleri Dergisi, 4 (1), 24-43.

Bhutta, M. Khurrum S. (2003). Supplier Selection Problem: Methodology Literature Review, Journal of International Information Management, 12(2), 53-72.

Buckley, J. J. (1985). Fuzzy hierarchical analysis. Fuzzy sets and systems, 17(3), 233-247.

Chai, J., Liu, J. N., \& Ngai, E. W. (2013). Application of decision-making techniques in supplier selection: A systematic review of literature. Expert Systems with Applications, 40(10), 3872-3885.

Chang, D. Y. (1996). Applications of the extent analysis method on fuzzy AHP. European journal of operational research, 95(3), 649-655.

Chatterjee, P., Athawale, V. M., \& Chakraborty, S. (2011). Materials selection using complex proportional assessment and evaluation of mixed data methods. Materials \& Design, 32(2), 851-860.

Chen, C. T. (2001). A fuzzy approach to select the location of the distribution center. Fuzzy sets and systems, 118(1), 65-73.

Cheng, C. H. (1996). Evaluating naval tactical missile systems by fuzzy AHP based on the grade value of membership function. European Journal of Operational Research, 96(2), 343-350.

Cheraghi, S. H., Dadashzadeh, M., \& Subramanıan, M. (2004). Critical success factors for supplier selection: an update. Journal of Applied Business Research (JABR), 20(2), 91-108.

Dağdeviren, M. (2007). Bulanik analitik hiyerarşi prosesi ile personel seçimi ve bir uygulama. Gazi Üniversitesi Mühendislik-Mimarlık Fakültesi Dergisi, 22(4).

De Boer, L., Labro, E., \& Morlacchi, P. (2001). A review of methods supporting supplier selection. European Journal of Purchasing \& Supply Management, 7(2), 75-89.

Degraeve, Z., Labro, E., Roodhooft, F., (2000). An evaluation of supplier selection methods from a Total Cost of Ownership perspective. European Journal of Operational Research 125 (1), 34-59.

Demirel, T., Demirel, N. Ç., \& Kahraman, C. (2008). Fuzzy analytic hierarchy process and its application. In Fuzzy multi-criteria decision making (pp. 53-83). Springer, Boston, MA.

Dickson, G.W. (1966). "An analysis of vendor selection systems and decisions", Journal of Purchasing 2/1, 5-17.

Fouladgar, M. M., Yazdani-Chamzini, A., Lashgari, A., Zavadskas, E. K., \& Turskis, Z. (2012b). Maintenance strategy selection using AHP and COPRAS under fuzzy environment. International Journal of Strategic Property Management, 16, 85-104. http://doi.org/10.3846/1648715X.2012.666657

Genovese, A., Koh, S. L., Bruno, G., \& Bruno, P. (2010). Green supplier selection: A literature review and a critical perspective. 8th International Conference on Supply Chain Management and Information Systems (SCMIS), pp. 1-6.

Girginer, N. (2008). Ticari Kredi Taleplerinin Degerlendirilmesine Çok Kriterli Yaklasim: Özel ve Devlet Bankasi Karsilastirmasi, Muhasebe ve Finansman Dergisi, 37, 132-142.

Govindan, K., Rajendran, S., Sarkis, J., \& Murugesan, P. (2013). Multi criteria decision making approaches for green supplier evaluation and selection: a literature review. Journal of Cleaner Production, 98, 66-83.

Göksu, A., \& Güngör, İ. (2008). Bulanik Analitik Hiyerarşik Proses ve Üniversite Tercih Siralamasinda Uygulanmasi. Süleyman Demirel Üniversitesi İktisadi ve İdari Bilimler Fakültesi Dergisi, 13(3), 1-26.

Ho, W., Xu, X., \& Dey, P. K. (2010). Multi-criteria decision making approaches for supplier evaluation and selection: A literature review. European Journal of Operational Research, 202(1), 16-24.

Holt, G.D., (1998). Which contractor selection methodology?. International Journal of Project Management 16 (3), 153-164.

Kağnıcıoglu, C. H., (2012). “Tedarik Zinciri Yönetimi”, Üretim Yönetimi, ed. C.H. Kagnicioglu, 192-211, Anadolu Üniversitesi Yayini No:2584, Açikögretim Fakültesi Yayini No:1553 Eskisehir.

Kaklauskas, A., Zavadskas, E. K., Raslanas, S., Ginevicius, R., Komka, A., \& Malinauskas, P. (2006). Selection of low-e windows in retrofit of public buildings by applying multiple criteria method COPRAS: A Lithuanian case. Energy and Buildings, 38(5), 454-462. http://doi.org/10.1016/j.enbuild.2005.08.005 
Kaptanoğlu, D. \& Özok, A. F. (2006). Akademik Performans Değerlendirmesi İçin Bir Bulanık Model, İtüdergisi /d Mühendislik, 5(1), Kısım 2, 193-204.

Küçük, O., \& Ecer, F. (2008). İmalatçı İşletmelerde Uygun Tedarikçi Seçimi: Analitik Hiyerarşi Yöntemi İle Bir Kobi Uygulaması. Atatürk Üniversitesi İktisadi ve İdari Bilimler Dergisi, 22(2), 435-450.

Liou, T. S., \& Wang, J. J., (1992). "Ranking Fuzzy Numbers with Index of Optimism”, Fuzzy Sets and Systems, Vol. 35, (1992b), s.143-150.

Lootsma, F. A., (1981). Performance Evaluation of Non-linear Optimization Methos via Multi-criteria Decision Analysis and via Linear Model Analysis, in: M. J. D. Powell, Ed. Nonlinear Optimization, London: Academic Press, 419-453.

Noorul Haq, A \& Kannan, G. (2006). Fuzzy analytical hierarchy process for evaluating and selecting a vendor in a supply chain model. The International Journal of Advanced Manufacturing Technology, 29(7-8), 826-835.

Nourianfar, K., \& Montazer, G. A. (2013). A fuzzy MCDM approach based on COPRAS method to solve supplier selection problems. 5th conference on information and knowledge technology (pp. 231-235). doi:10.1109/IKT.2013.6620070

Ös, E., (2010). Denetim Evreninin Belirlenmesinde Alternatif Bir Yöntem: Analitik Hiyerarsi Prosesi”, Denetisim, 4, 8-16.

Özbek, A. ve Eren, T. (2013). Multiple criteria decision making methods for selecting third party logistics firms: a literature review. Sigma, 31, 178-202.

Özgörmüş E., Mutlu, Ö. ve Güner H. (2005) "Bulanık AHP ile Personel Seçimi” V. Ulusal Üretim Araştırmaları Sempozyumu, Kasim 25-27, İstanbul.

Raharjo, H., Xie, M. \& Brombacher, A., (2009). On Modelling Dynamic Priorities In The Analytic Hierarchy Process Using Composition Data Analysis, European Journal of Operational Research, 194, 834-839.

Saaty, T.L., (1980). The Analytic Hierarchy Process, McGraw-Hill International Book Company, USA.

Sahu, Nitin Kumar, Saurav Datta, Siba Sankar Mahapatra, (2012). "Establishing green supplier appraisement platform using grey concepts", Grey Systems: Theory and Application , 2(3), 395-418, doi: 10.1108/20439371211273276

Setak, M., Sharifi, S., \& Alimohammadian, A. (2012). Supplier selection and order allocation models in supply chain management: a review. World applied sciences journal, 18(1), 55-72.

Sipahi, S. \& Or, E., (2005). Analitik Hiyerarsi Prosesi Teknigi Ile Forvet Oyuncularinin Yetenek ve Becerilerine Göre Degerlendirilmesi, Yönetim, 50, 53-65.

Sönmez, M. (2006). Review and critique of supplier selection process and practices. (C) Loughborough University.

Timor, M., (2011). Kolayda Ürünler Için Perakende Satis Yeri Seçimi: Bir Analitik Hiyerarsi Prosesi Uygulamasi, Yönetim, 3(41), 23-36.

Timur, M. N., (2013). Tedarik Zinciri-Temel Kavramlar, Tedarik Zinciri Yönetimi, ed. Timur, M. N. ve Çekerol, G. S., 2-23, Anadolu Üniversitesi Yayini No:2889, Açikögretim Fakültesi Yayini No: 1846, Eskisehir,

Tolga, A. Ç., \& Kahraman, C. (2009). Yazılım Geliştirme Projelerinin Gerçek Opsiyon Değerleme Modeliyle Çok Ölçütlü Bulanık Değerlemesi. İstanbul Ticaret Üniversitesi Fen Bilimleri Dergisi, 8(15), 13-26.

Van Laarhoven, P. J. M., \& Pedrycz, W. (1983). A fuzzy extension of Saaty's priority theory. Fuzzy sets and Systems, 11(1-3), 229-241.

Ware, N., Sing, S., \& Banwet, D. (2012). Supplier selection problem: A state-of-the-art review. Management Science Letters, 2(5), 1465-1490.

Weber, C.A., Current, J.R., \& Benton, W.C., (1991). Vendor selection criteria and methods. European Journal of Operational Research 50, 2-18.

Wu, C., \& Barnes, D. (2011). A literature review of decision-making models and approaches for partner selection in agile supply chains. Journal of Purchasing and Supply Management, 17(4), 256-274.

Yıldırım, B. F. (2014). Gri İlişkisel Analiz, Çok Kriterli Karar Verme Yöntemleri, Editörler: Bahadır Fatih Yildirim ve Emrah Önder, (1. Baski, 227-242) Bursa: Dora Yayincilik.

Yılmaz, M., (2010). Analitik Hiyerarsi Süreci (AHS) ve Bir Uygulama: Lider Bir Kütüphane Müdürü Seçimi, Türk Kütüphaneciliği, 24(2), 206.234. 
Zavadskas, E. K., Kaklauskas, A., Turskis, Z., \& Tamosaitiene, J. (2008). Contractor selection multi-attribute model applying COPRAS method with grey interval numbers. In 20th EURO Mini Conference "Continuous Optimization and Knowledge-Based Technologies" 241-247. 